\title{
Lignin-Derived Syringol and Acetosyringone from Palm Bunch Using Heterogeneous Oxidative Depolymerization over Mixed Metal Oxide Catalysts under Microwave Heating
}

\author{
Rangsalid Panyadee ${ }^{1}$, Aphinan Saengsrichan ${ }^{1}$, Pattaraporn Posoknistakul ${ }^{1}$, Navadol Laosiripojana ${ }^{2}$, \\ Sakhon Ratchahat ${ }^{1}$, Babasaheb M. Matsagar ${ }^{3} \mathbb{D}$, Kevin C.-W. Wu ${ }^{3,4,5}$ iD and Chularat Sakdaronnarong ${ }^{1, *}$ (D)
}

1 Department of Chemical Engineering, Faculty of Engineering, Mahidol University, 999 Putthamonthon 4 Road, Salaya, Putthamonthon, Nakorn Pathom 73170, Thailand; rangsalid.p@gmail.com (R.P.); aphinan.sae@student.mahidol.edu (A.S.); pattaraporn.pos@mahidol.edu (P.P.); sakhon.rat@mahidol.edu (S.R.)

2 The Joint Graduate School of Energy and Environment (JGSEE), King Mongkut's University of Technology Thonburi, 126 Pracha Uthit Road, Bang Mot, Tungkru, Bangkok 10140, Thailand; navadol@jgsee.kmutt.ac.th

3 Department of Chemical Engineering, National Taiwan University, No.1, Sec. 4 Roosevelt Road, Taipei City 10617, Taiwan; bmatsagar22@gmail.com (B.M.M.); kevinwu@ntu.edu.tw (K.C.-W.W.)

4 Center of Atomic Initiative for New Materials (AI-MAT), National Taiwan University, Taipei City 10617, Taiwan

check for updates

Citation: Panyadee, R.; Saengsrichan, A.; Posoknistakul, P.; Laosiripojana,

N.; Ratchahat, S.; Matsagar, B.M.; Wu, K.C.-W.; Sakdaronnarong, C. Lignin-Derived Syringol and Acetosyringone from Palm Bunch Using Heterogeneous Oxidative Depolymerization over Mixed Metal Oxide Catalysts under Microwave Heating. Molecules 2021, 26, 7444. https://doi.org/10.3390/ molecules26247444

Academic Editor: Gregory Chatel

Received: 21 September 2021 Accepted: 6 December 2021 Published: 8 December 2021

Publisher's Note: MDPI stays neutral with regard to jurisdictional claims in published maps and institutional affiliations.

Copyright: (c) 2021 by the authors. Licensee MDPI, Basel, Switzerland. This article is an open access article distributed under the terms and conditions of the Creative Commons Attribution (CC BY) license (https:/ / creativecommons.org/licenses/by/ $4.0 /)$.
5 International Graduate Program of Molecular Science and Technology, National Taiwan University (NTU), Taipei City 10617, Taiwan

* Correspondence: chularat.sak@mahidol.ac.th

Abstract: Biomass valorization to building block chemicals in food and pharmaceutical industries has tremendously gained attention. To produce monophenolic compounds from palm empty fruit bunch (EFB), EFB was subjected to alkaline hydrothermal extraction using $\mathrm{NaOH}$ or $\mathrm{K}_{2} \mathrm{CO}_{3}$ as a promotor. Subsequently, EFB-derived lignin was subjected to an oxidative depolymerization using $\mathrm{Cu}(\mathrm{II})$ and $\mathrm{Fe}(\mathrm{III})$ mixed metal oxides catalyst supported on $\gamma-\mathrm{Al}_{2} \mathrm{O}_{3}$ or $\mathrm{SiO}_{2}$ as the catalyst in the presence of hydrogen peroxide. The highest percentage of total phenolic compounds of $63.87 \mathrm{wt} \%$ was obtained from microwave-induced oxidative degradation of $\mathrm{K}_{2} \mathrm{CO}_{3}$ extracted lignin catalyzed by $\mathrm{Cu}-\mathrm{Fe} / \mathrm{SiO}_{2}$ catalyst. Main products from the aforementioned condition included $27.29 \mathrm{wt} \%$ of 2,4-di-tert-butylphenol, $19.21 \mathrm{wt} \%$ of syringol, $9.36 \mathrm{wt} \%$ of acetosyringone, $3.69 \mathrm{wt} \%$ of acetovanillone, $2.16 \mathrm{wt} \%$ of syringaldehyde, and $2.16 \mathrm{wt} \%$ of vanillin. Although the total phenolic compound from $\mathrm{Cu}-\mathrm{Fe} / \mathrm{Al}_{2} \mathrm{O}_{3}$ catalyst was lower (49.52 wt \%) compared with that from $\mathrm{Cu}-\mathrm{Fe} / \mathrm{SiO}{ }_{2}$ catalyst $(63.87 \mathrm{wt} \%), \mathrm{Cu}-\mathrm{Fe} / \mathrm{Al}_{2} \mathrm{O}_{3}$ catalyst provided the greater selectivity of main two value-added products, syringol and acetosyrigone, at $54.64 \%$ and $23.65 \%$, respectively $(78.29 \%$ total selectivity of two products) from the $\mathrm{NaOH}$ extracted lignin. The findings suggested a promising method for syringol and acetosyringone production from the oxidative heterogeneous lignin depolymerization under low power intensity microwave heating within a short reaction time of $30 \mathrm{~min}$.

Keywords: alkaline hydrothermal lignin fractionation; heterogeneous catalyst; phenolic compound; microwave-assisted lignin depolymerization; mixed iron and copper oxide catalyst

\section{Introduction}

To produce high-valued phenolic compounds from lignin, the researchers have proposed both thermochemical reactions, e.g., based-catalyzed/acid-catalyzed depolymerization [1,2], hydrogenation [3,4], hydrogenolysis [5,6], combustion [7], gasification [8], pyrolysis [9,10], and catalytic oxidation [11] approaches. In the past decades, hydrothermal reaction under high pressure and temperature has been proposed to produce either aromatic compounds or bio-oil from biomass $[12,13]$. In hydrothermal reactions, water was used as a reaction medium. At subcritical condition with high temperature and high pressure, water acts as catalyst behaving both basic and acidic properties. Apart from 
water, many other solvents could be used as the reaction medium to facilitate better reaction efficiency such as superior selectivity, higher reaction rate, and greater product yield. Moreover, both homogeneous and heterogeneous catalysts could be used to improve the reaction performance [14]. Advantages of hydrothermal technique were the higher yield of phenolic compounds as well as economical and simple handling. Recently, Chan et al. (2015) studied the process parameters for the hydrothermal liquefaction of waste from the palm oil industry for phenolic bio-oil production [15]. The proposed technology although provides high phenolic compound yield, a great amount of energy is required as the temperature range of hydrothermal liquefaction over $350{ }^{\circ} \mathrm{C}$ is applied. In addition, the high capital expenditure due to the high-pressure vessel beyond $8 \mathrm{MPa}$ is needed depending on the solvents used in the reaction. Apart from that, a previous research reported successful vanillin production under thermal condition $\left(400-600{ }^{\circ} \mathrm{C}\right)$ that required special reactor having capability to control reaction time down to 40-600 s [16]. Therefore, two-step lignin fractionation followed by lignin depolymerization under mild hydrothermal reaction in alkaline condition has been proposed in the present work.

In case of lignin depolymerization to phenolic compounds, there were five types of reactions commonly used, consisting of metallic-catalyzed, base-catalyzed, acid-catalyzed, ionic liquids (ILs)-induced, and supercritical solvolysis lignin depolymerization reactions. It was found that vanillin was successfully produced from dissolution of kraft lignin and eucalyptus via ILs pretreatment at $160^{\circ} \mathrm{C}$ for $6 \mathrm{~h}$ while syringol and allyl guaiacol were the major products observed from dissolution of switch grass and pine, respectively [17]. Various ILs assisted lignin depolymerization processes with high selectivity were also proposed [18-20], but the ILs cost and recyclability are limitations. Ordinarily, base-catalyzed and acid-catalyzed depolymerization reaction were conscientious, but low selectivity was obtained. Not only the strong reaction conditions (high temperature, high pressure and high $\mathrm{pH}$ ) but also requirement of extraordinarily designed reactors, resulted in high costs of phenolics production. Further, supercritical fluids although provides high selectivity than acid and base-catalyzed reactions, nevertheless supercritical solvents facility limited their applications on biomass treatment in commercial scale [21,22]. Conversion of lignin to vanillin or phenolic aldehydes e.g., $p$-hydroxybenzaldehyde, vanillaldehyde, syringaldehyde [23], which are used in pharmaceutical application, has been widely studied via mild oxidative reaction that required either air, molecular oxygen [24] or oxidant such as $\mathrm{H}_{2} \mathrm{O}_{2}$ [25-27].

Additionally, metal-catalyzed oxidative lignin depolymerization has offered great advantages because of its high selectivity and relatively milder reaction condition; therefore, metal supported catalysts have been extensively used for lignin valorization [13,28,29]. It has been reported that $\mathrm{Au} / \mathrm{TiO}_{2}$, however, favored ring-opening reactions of lignin while $\mathrm{Pt} / \mathrm{TiO}_{2}$ effectively promoted lignin condensation and gave minimal effect on ringopening reaction [30]. Although precious metal-supported catalysts are efficient for the valorization of lignin, their utilization is not economically feasible because of limited availability and high cost. To avoid these issues, non-precious metal supported catalysts have been introduced for the efficient heterogeneous lignin depolymerization. Among all metal complex investigated, the copper complexes could influence the mechanism in accordance with formation of monophenolic compounds. It was revealed that the $\mathrm{Cu}$ and La-doped porous metal oxide-based catalysts derived from hydrotalcite-like precursors were promising catalysts for the depolymerization of organosolv lignin in supercritical methanol [31]. In this method, lignin was depolymerized to methanol-soluble products without any char formation. The obtained bio-oil contains oligomers with high aromatic content and phenolic monomers. Most of early research on lignin oxidation was proceeded with oxidant or with $\mathrm{Zr}^{4+}, \mathrm{Mn}^{3+}, \mathrm{Co}^{2+}$ and $\mathrm{Cu}^{2+}$ which were simple transition metal ions [32,33]. After that, $\mathrm{Mn}, \mathrm{Co}, \mathrm{Cu}$ and Fe based metal oxides (e.g., $\mathrm{CuO}, \mathrm{MnO}_{2}$ ), metal chlorides (e.g., $\mathrm{MnCl}_{2}, \mathrm{CoCl}_{2}, \mathrm{FeCl}_{3}$ ) [26,34] and composite metal oxides were subsequently investigated to augment oxygen catalytic efficiency for lignin depolymerization [35-38]. 
Recently, lignin depolymerization using microwave heating has been widely investigated due to its high heating rate and more selective to break down particular bonding thus yielding high selectivity of desire products based on individual catalyst compared with conventional heating approaches $[4,39,40]$. Liu and colleagues newly reported on lignin degradation in isopropanol with very high liquid yield at $45.35 \mathrm{wt} \%$ within only $30 \mathrm{~min}$ under microwave heating at $120{ }^{\circ} \mathrm{C}$ [39]. Even higher liquid product yield at $72.0 \mathrm{wt} \%$ including $6.7 \mathrm{wt} \%$ monomers, mainly 2,3-dihydrobenzofuran (3.00 $\mathrm{wt} \%$ ) and p-coumaric acid $(1.59 \mathrm{wt} \%)$, from alkaline lignin depolymerization at $160{ }^{\circ} \mathrm{C}$ in formic acid/methanol media were achieved within $30 \mathrm{~min}$ [40]. A study just newly revealed the catalytic C-O-C bond scission of birch sawdust lignin promoted by $\mathrm{Fe}(\mathrm{OTf})_{3}$ under the identical conditions $\left(190{ }^{\circ} \mathrm{C}, 1 \mathrm{~h}\right.$ ), which yielded more selective syringyl unit (S) of lignin monomer compared with guaiacyl-unit $(\mathrm{G})$ of lignin [41]. Similar result of C-O-C ether bond cleavage was found when $\mathrm{Rh} / \mathrm{C}$ was the catalyst and formic acid was used as the reaction medium under microwave heating [13]. Just newly reported, microwave-assisted catalytic depolymerization of birch sawdust lignin over $\mathrm{Pt} / \mathrm{C}, \mathrm{Pd} / \mathrm{C}$, or $\mathrm{Ru} / \mathrm{C}$ in water/alcohol mixture facilitated in situ hydrogen generated and simultaneously promoted the hydrogenolysis of $\beta-O-4$ ether linkage which markedly yield S-type lignin relatively to Guaiacyl or G-type lignin as main products [42]. The result was in good agreement with our previous study on microwave-assisted depolymerization of alkaline lignin from palm bunch over dual $\mathrm{Cu}(\mathrm{OH})_{2}$ and $\mathrm{Fe}_{2} \mathrm{O}_{3}$ catalysts which gave highly selective syringyl-type products within only $15 \mathrm{~min}$ [26].

In the present work, based on our previous study Fe and $\mathrm{Cu}$ exhibited very good performance on lignin depolymerization under mild microwave heating in the presence of $\mathrm{H}_{2} \mathrm{O}_{2}$ in homogeneous catalytic system [26]. A high yield of oxidative lignin depolymerization products, namely, syringol, acetosyringone and vanillin, were produced with high selectivity. Therefore, heterogeneous $\mathrm{Fe}$ and $\mathrm{Cu}$ based mixed metal oxide catalysts were synthesized on various supports and used as the catalysts for the depolymerization of the EFB derived alkaline lignin to produce monophenolic compounds. To the best of our knowledge, there was no report on investigation of mixed metal oxide $\mathrm{Fe}_{2} \mathrm{O}_{3} / \mathrm{CuO} / \mathrm{SiO}_{2}$ and $\mathrm{Fe}_{2} \mathrm{O}_{3} / \mathrm{CuO} / \mathrm{Al}_{2} \mathrm{O}_{3}$ used as catalyst in oxidative lignin depolymerization. Therefore, heterogeneously mixed metal oxide $\left(\mathrm{Fe}_{2} \mathrm{O}_{3}\right.$ and $\left.\mathrm{CuO}\right)$ catalysts were synthesized on different supports $\left(\mathrm{SiO}_{2}\right.$ or $\left.\mathrm{Al}_{2} \mathrm{O}_{3}\right)$ and their catalytic activity under oxidative condition using microwave heating were compared. The synthesized catalyst was easily recovered by filtration or centrifugation that is beneficial for recycling the catalyst. The results from homogeneous catalytic lignin depolymerization and heterogeneous catalytic reaction were compared.

\section{Materials and Methods}

\subsection{Biomass and Chemicals}

To prepare the material for lignin extraction, raw EFB from a palm oil mill having initial moisture content at $~ 50 \%$ was washed with water and sun-dried for $12 \mathrm{~h}$. After that, it was dried at $80^{\circ} \mathrm{C}$ in an oven for $24 \mathrm{~h}$ to obtain $4.3 \%$ final moisture content. Then, dried EFB was crushed and sieved to the particle size in a range of $+50 /-200$ mesh $(74-297 \mu \mathrm{m})$, and stored in a desiccator for use. For catalyst synthesis, silicon dioxide $\left(\mathrm{SiO}_{2}\right)$ and aluminium oxide $\left(\mathrm{Al}_{2} \mathrm{O}_{3}\right)$ were purchased from KemAus, Australia and used as the catalyst support. Copper (II) nitrate $\left(\mathrm{Cu}\left(\mathrm{NO}_{3}\right)_{2}\right)$ and iron (III) nitrate $\left(\mathrm{Fe}\left(\mathrm{NO}_{3}\right)_{3}\right)$ were obtained from Ajax Finechem, Australia. For lignin separation from EFB, the chemicals namely potassium carbonate (99.8\%, Daejung, Siheung-si, Korea), sodium hydroxide (99.8\%, Ajax Finechem, New South Wales, Australia), hydrogen peroxide ( $30 \% w / w$, Ajax), sulfuric acid ( $98 \%$, RCI Labscan, Bangkok, Thailand), and hydrochloric acid (37\%, RCI Labscan) were purchased and used as received. Solvents for phenolic compound extraction and GC-MS analysis such as methanol (99.8\%, HPLC, RCI Labscan) and ethyl acetate (99.5\%, Daejung) were acquired and used as received. 


\subsection{Co-Impregnation of $\mathrm{SiO}_{2}, \mathrm{Al}_{2} \mathrm{O}_{3}$ Supported $\mathrm{Cu}$-Fe Catalysts for EFB-Extracted} Lignin Depolymerization

Both the $\mathrm{Cu}$ and $\mathrm{Fe}$ loadings of the catalysts were $10 \mathrm{~mol} \%$ based on $\mathrm{SiO}_{2}$ and $\mathrm{Al}_{2} \mathrm{O}_{3}$. The aqueous mixture solution of $\mathrm{Cu}\left(\mathrm{NO}_{3}\right)_{2}$ and $\mathrm{Fe}\left(\mathrm{NO}_{3}\right)_{3}$ were prepared and added dropwise in the $\mathrm{SiO}_{2}$ or $\mathrm{Al}_{2} \mathrm{O}_{3}$ in a crucible. The slurry was evaporated in ambient atmosphere for $8 \mathrm{~h}$, then dried at $110{ }^{\circ} \mathrm{C}$ overnight, and calcined in furnace at $350{ }^{\circ} \mathrm{C}$ in an excess air for $4 \mathrm{~h}$, as shown in Figure 1 . The calcined $\mathrm{Cu}-\mathrm{Fe} / \mathrm{Al}_{2} \mathrm{O}_{3}$ and $\mathrm{Cu}-\mathrm{Fe} / \mathrm{SiO}_{2}$ catalysts were stored in an automatic desiccator at $<25 \%$ relative humidity.

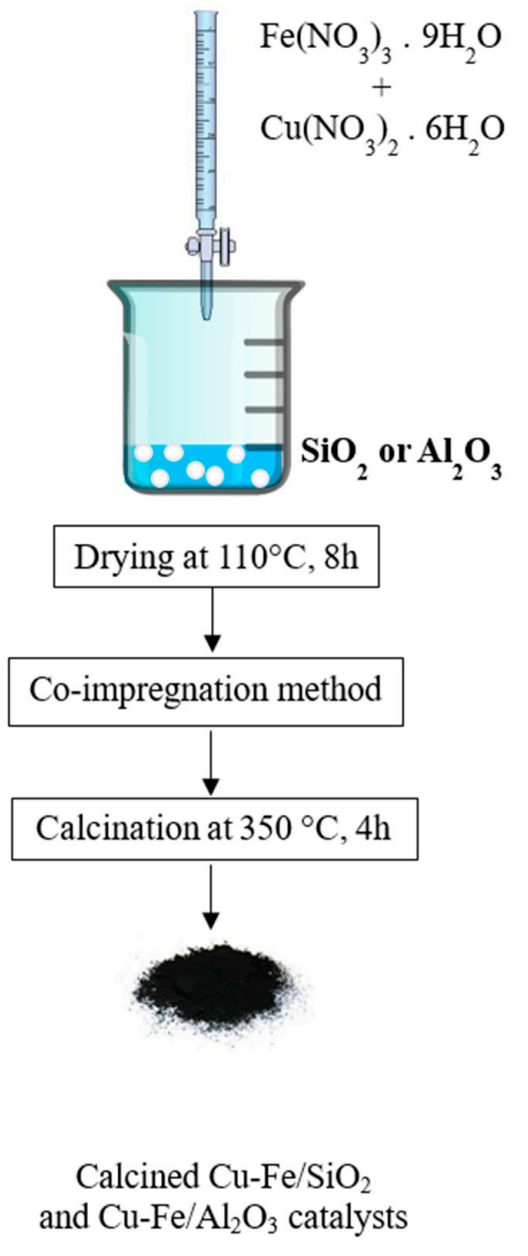

Figure 1. Co-impregnation of $\mathrm{Cu}-\mathrm{Fe}$ catalysts on $\mathrm{SiO}_{2}$ or $\mathrm{Al}_{2} \mathrm{O}_{3}$ supports.

\subsection{Heterogeneously Mixed Metal Oxides Complex Catalysts Characterization}

The crystal structure of heterogeneously mixed metal oxides catalysts was characterized by X-ray diffractometry (XRD, D8 Advance, Bruker, Bremen, Germany) with scan rate at $1^{\circ} \mathrm{min}^{-1}$ and $2 \theta$ range from $10^{\circ}$ to $70^{\circ}$. The surface elemental composition of the calcined catalysts was determined by X-ray photoelectron spectroscopy (XPS, AXIS Nova, Kratos, Manchester, UK). Quasi-quantitative analysis of metal oxides in calcined catalysts was performed using X-ray Fluorescence Spectrometer (XRF, model Rigaku ZSK Primus, Rigaku, Tokyo, Japan). The appearance and elemental composition of catalysts were analyzed by Scanning electron microscopy with energy-dispersive X-ray spectroscopy (SEM-EDX) (VEGA3, TESCAN Brno-Kohoutovice, Czech Republic). Field Emission Scanning Electron Microscope (FE-SEM) model JEOL JSM7800F, JAPAN, Software: PCSEM equipped with Energy Dispersive X-ray Spectrometer (EDS) model Oxford X-Max 20, United Kingdom (UK) was used for analysis of elemental dispersion on catalyst surface with accelerating voltage of $15 \mathrm{kV}$ at 2500-5000 magnification. Analysis of ammonia-temperature programmed 
desorption ( $\mathrm{NH}_{3}$-TPD) using chemisorption analyzer (BEL Japan Inc.) was applied to quantify the acid density and the distribution of acid sites of synthesized catalysts and the support in a temperature range of 100 and $700{ }^{\circ} \mathrm{C}$.

\subsection{Lignin Extraction and Depolymerization of Lignin}

\subsubsection{Alkali Hydrothermal Extraction of Lignin from Palm Empty Fruit Bunch}

Lignin extraction from EFB was described in our previous study [26]. First, dried EFB was crushed to small particles and sieved to a range of $+50 /-200$ mesh. Then, lignin fractionation from EFB using alkaline solution $\left(1 \mathrm{~mol} \mathrm{~L}^{-1} \mathrm{~K}_{2} \mathrm{CO}_{3}\right.$ or $\mathrm{NaOH}$ solution) was conducted in a high-pressure stainless-steel hydrothermal reactor with solid-to-liquid ratio of 1:5. The reaction was performed at $200{ }^{\circ} \mathrm{C}$ for $20 \mathrm{~min}$ under $2 \mathrm{MPa}$ nitrogen pressure. For lignin precipitation, lignin-rich solution from alkali hydrothermal extraction was acidified with concentrated sulfuric acid until final $\mathrm{pH}$ of solution was 1.0. The solid precipitate was separated from solution by centrifuge at $7000 \mathrm{rpm}$ at $25^{\circ} \mathrm{C}$ for $15 \mathrm{~min}$. Then, solid precipitated lignin was washed with distilled water until the $\mathrm{pH}$ became neutral. Finally, alkaline extracted lignin was dried at $50{ }^{\circ} \mathrm{C}$ for $18 \mathrm{~h}$ and used as the precursor for the production of phenolic compounds.

2.4.2. Microwave-Assisted Phenolic Compound Production over Heterogeneously Mixed Metal Oxides Complex Catalyst

The reaction catalyzed by $\mathrm{Cu}(\mathrm{OH})_{2}+\mathrm{Fe}_{2} \mathrm{O}_{3}$ mixed metal oxides catalyst with $1 \mathrm{wt} \%$ and $2.5 \mathrm{wt} \% \mathrm{H}_{2} \mathrm{O}_{2}$ was selected as it was the best condition for homogeneous monophenolic compound production from $\mathrm{K}_{2} \mathrm{CO}_{3}$-lignin and $\mathrm{NaOH}$-lignin, respectively. Based on our previous study [26], the reaction was carried out under microwave irradiation at $300 \mathrm{~W}$ for 15 and 30 min for $0.3 \mathrm{~g} \mathrm{~K}_{2} \mathrm{CO}_{3}$-lignin or $\mathrm{NaOH}$-lignin with $0.15 \mathrm{~g}$ of heterogeneously mixed metal oxide catalyst and $1 \mathrm{wt} \%$ of $\mathrm{H}_{2} \mathrm{O}_{2}$ as an oxidant in the presence of $3 \mathrm{~mol} \mathrm{~L}^{-1}$ $\mathrm{NaOH}$ solution as demonstrated in Figure 2.

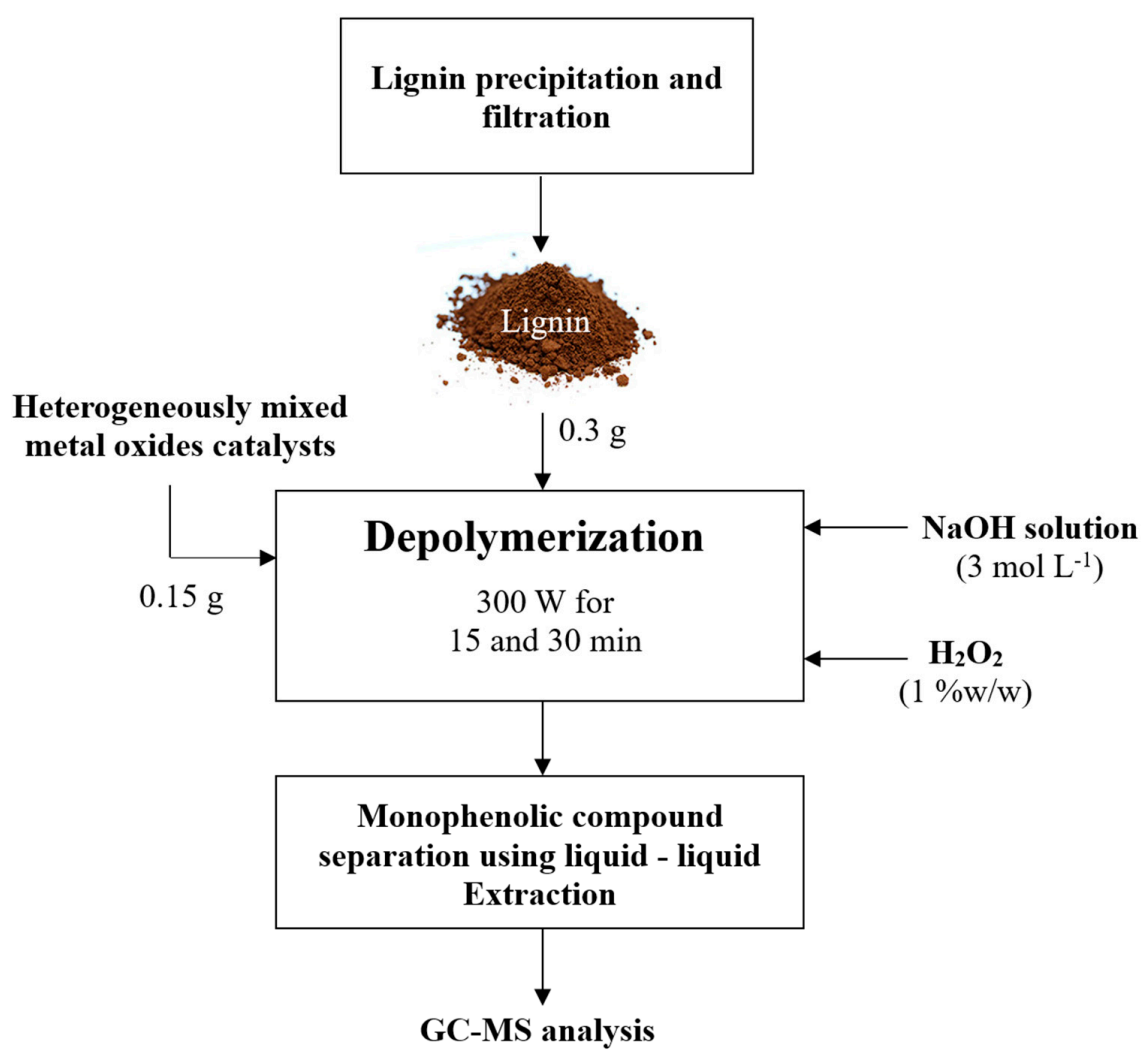

Figure 2. Experimental diagram of EFB depolymerization process in a microwave reactor with mixed metal oxides complex heterogeneous catalysts. 
Recyclability of both $\mathrm{CuFe} / \mathrm{Al}_{2} \mathrm{O}_{3}$ and $\mathrm{CuFe} / \mathrm{SiO}_{2}$ catalysts on $\mathrm{NaOH}$-lignin in microwave depolymerization at $300 \mathrm{~W}$ for $30 \mathrm{~min}$ was studied. Spent catalysts after the first reaction was filtered and washed several times with methanol to eliminate lignin contamination. Dry catalysts at $60^{\circ} \mathrm{C}$ for $12 \mathrm{~h}$ were used for the subsequent reaction with the same weight ratio of catalyst to lignin when solid-to-liquid ratio was constant for all catalyst recycle studies. Spent catalysts were characterized using XPS for elemental analysis compared with fresh catalyst.

\subsection{Analysis of Lignin Functional Groups and Lignin Depolymerization Products}

Analysis of $\mathrm{K}_{2} \mathrm{CO}_{3}$-lignin and $\mathrm{NaOH}$-lignin was performed after acid precipitation of lignin from alkali hydrothermal extraction using sulfuric acid, $\mathrm{pH}$ 1.0. The precipitate was centrifuged and dried at $50^{\circ} \mathrm{C}$ for $18 \mathrm{~h}$. Fourier transform infrared (FT-IR) spectroscopy (Nicolet 6700, Thermo Fisher Scientific, Waltham, MA, USA) was used to analyze functional groups of extracted lignin at the wavenumber ranging from 4000 to $400 \mathrm{~cm}^{-1}$ with $4 \mathrm{~cm}^{-1}$ resolution and 100 scan numbers. In order to identify and compare the different amounts of functional groups, $0.01 \mathrm{~g}$ lignin sample was mixed with $0.99 \mathrm{~g} \mathrm{KBr}$ for palletization prior to FT-IR spectroscopy. In case of analysis of lignin depolymerization product from microwave reaction, ethyl acetate extraction of monophenolic compounds from the liquid products from depolymerization reaction was conducted, subsequently the solvent was evaporated under vacuum, and the dry product was re-dissolved in methanol for gas chromatography mass spectrometry (GC-MS) analysis (Agilent GC6890N, Wilmington, DE, USA). The extracts dissolved in methanol $(1 \mu \mathrm{L})$ was injected into the capillary HP-5 MS column $(30 \mathrm{~m} \times 0.25 \mathrm{~mm} \times 0.25 \mu \mathrm{m})$ controlled at $250^{\circ} \mathrm{C}$ using splitless mode. Helium was used as a carrier gas with a flow rate of $1 \mathrm{~mL} \mathrm{~min}^{-1}$. In case of product quantification, known concentration of main products in the reaction mixture (e.g., syringol, vanillin, acetosyringol, acetovanillone, syringaldehyde, and 2,4-di-tert-butylphenol) was analyzed by gas chromatography-flame ionization detector (GC-FID, model Clarus 580, Perkin Elmer, Waltham, MA, USA).

\section{Results and Discussion}

\subsection{Extracted Lignin from $E F B$}

The properties of extracted lignin from EFB using $\mathrm{K}_{2} \mathrm{CO}_{3}$ and $\mathrm{NaOH}$ solution in hydrothermal reactor were reported elsewhere [26]. As shown in Figure 3, FT-IR spectra of $\mathrm{NaOH}$-lignin and $\mathrm{K}_{2} \mathrm{CO}_{3}$-lignin were noticeably different especially methyl $\left(\mathrm{CH}_{3}\right)$ intensity compared with the control when lignin was hydrothermally extracted without alkali. FT-IR peaks could be used to identify the presence of $\mathrm{CH}_{3}$ group in extracted lignin indicating by peak intensity at wave number of $1028-1052 \mathrm{~cm}^{-1}$ (symmetry $\mathrm{O}-\mathrm{CH}_{3}$ vibration), $\sim 1176 \mathrm{~cm}^{-1}\left(\rho \mathrm{CH}_{3}\right)$ and $1442-1463 \mathrm{~cm}^{-1}\left(\delta_{\mathrm{s}} \mathrm{HCH}\left(\mathrm{CH}_{3}\right)\right)$ [43]. It was observed that methyl content in extracted lignin using different extractants was found in a respective degree; $\mathrm{NaOH}$-lignin $>\mathrm{H}_{2} \mathrm{O}$-lignin $>\mathrm{K}_{2} \mathrm{CO}_{3}$-lignin (Figure 3). $\mathrm{NaOH}$-lignin was found to contain the highest concentration of $\mathrm{CH}_{3}$ group. It was reported that hydroxide ions assist $\beta-\mathrm{O}-4$ ether bonds cleavage by acting as a nucleophile. $\mathrm{Na}+$ ions adducted with lignin molecules could polarize the ether bonds rendering an enhancement of negative charge of oxygen atom of the ether bond and thus the energy for heterolytic breakdown of the linkage is decreased [44]. After delignification and alkaline degradation, the obtained alkali lignin consists mainly of three phenyl-propane units. The reactive sites for heterogeneously catalytic conversion to phenolic compounds i.e., hydroxyl, methoxyl, and aldehyde groups were increased [45]. 


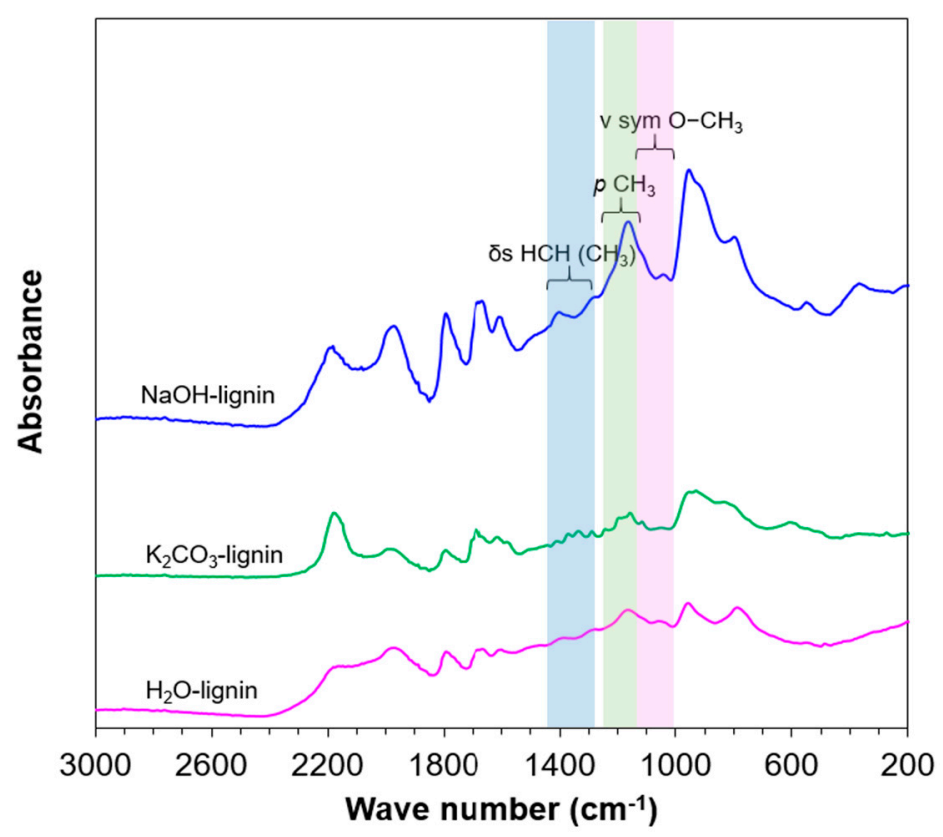

Figure 3. FT-IR spectroscopic analysis of $\mathrm{NaOH}$-lignin and $\mathrm{K}_{2} \mathrm{CO}_{3}$-lignin compared with the control $\left(\mathrm{H}_{2} \mathrm{O}\right.$-lignin) from the alkali hydrothermal lignin extraction with solid:liquid ratio of $1: 5$ at $200{ }^{\circ} \mathrm{C}$ for 20 min under $2 \mathrm{MPa}$ nitrogen pressure.

In contrast, alkali carbonates (i.e., $\mathrm{K}_{2} \mathrm{CO}_{3}$ ) were determined to influence a decrease of proton concentration during depolymerization reaction and led to enhancing parallel and secondary reaction mechanism to generate more phenols and conjugated phenolic compounds from demethylation of original lignin [46]. From the $\mathrm{K}_{2} \mathrm{CO}_{3}$ extraction condition, the smaller molecular weight lignin was obtained relative to $\mathrm{NaOH}$-lignin from gel permeation chromatography (GPC) due to greater amount of basic ions i.e., $\mathrm{K}^{+}$and $\mathrm{CO}_{3}{ }^{2-}$ compared with $\mathrm{Na}^{+}$and $\mathrm{OH}^{-}$at the similar molar concentration $\left(1 \mathrm{~mol} \mathrm{~L}^{-1}\right)$ [26]. $\mathrm{K}_{2} \mathrm{CO}_{3}$-lignin has smaller molecular weight of $1125 \mathrm{~g} \mathrm{~mol}^{-1}$ but lower polydispersity index (PD) of 1.53 when compared with $\mathrm{NaOH}$-lignin that yielded $1244 \mathrm{~g} \mathrm{~mol}^{-1}$ molecular weight with greater $\mathrm{PD}$ of 1.58 . These smaller $\mathrm{K}_{2} \mathrm{CO}_{3}$ extracted lignin molecules possibly tended to be more effortless to depolymerize to monophenolic products using heterogeneously mixed metal oxide catalyst and hydrogen peroxide in the following section.

\subsection{Characterization and Reactivity of the Heterogeneously Mixed Metal Oxides Catalysts on Phenolic Compounds Production}

3.2.1. X-ray Diffraction (XRD) and X-ray Fluorescence Spectrometry (XRF) of Heterogeneously Mixed Metal Oxide Catalysts

As demonstrated in Figure 4, the XRD patterns of $\mathrm{Cu}-\mathrm{Fe} / \mathrm{Al}_{2} \mathrm{O}_{3}$ and $\mathrm{Cu}-\mathrm{Fe} / \mathrm{SiO}_{2}$ catalysts show diffraction peaks at $2 \theta=35.4^{\circ}$ and $39.4^{\circ}$ corresponding to $\mathrm{CuO}$. Small peak attributable to $\mathrm{CuO}$ was observed, suggesting that $\mathrm{Cu}$ was present as amorphous or highly dispersed form on the support [47]. The peak at $33.4^{\circ}$ ascribed to the presence of $\mathrm{Fe}_{2} \mathrm{O}_{3}$ [48] were active phases for the lignin depolymerization reaction. A very broad peak at $2 \theta$ of $22.4^{\circ}$ observed on the catalyst was attributed to amorphous $\mathrm{SiO}_{2}$ and the peaks at $2 \theta=37.6^{\circ}, 46.1^{\circ}$, and $67^{\circ}$ were ascribed to the $\mathrm{Al}_{2} \mathrm{O}_{3}$ support (Figure 4 ). 


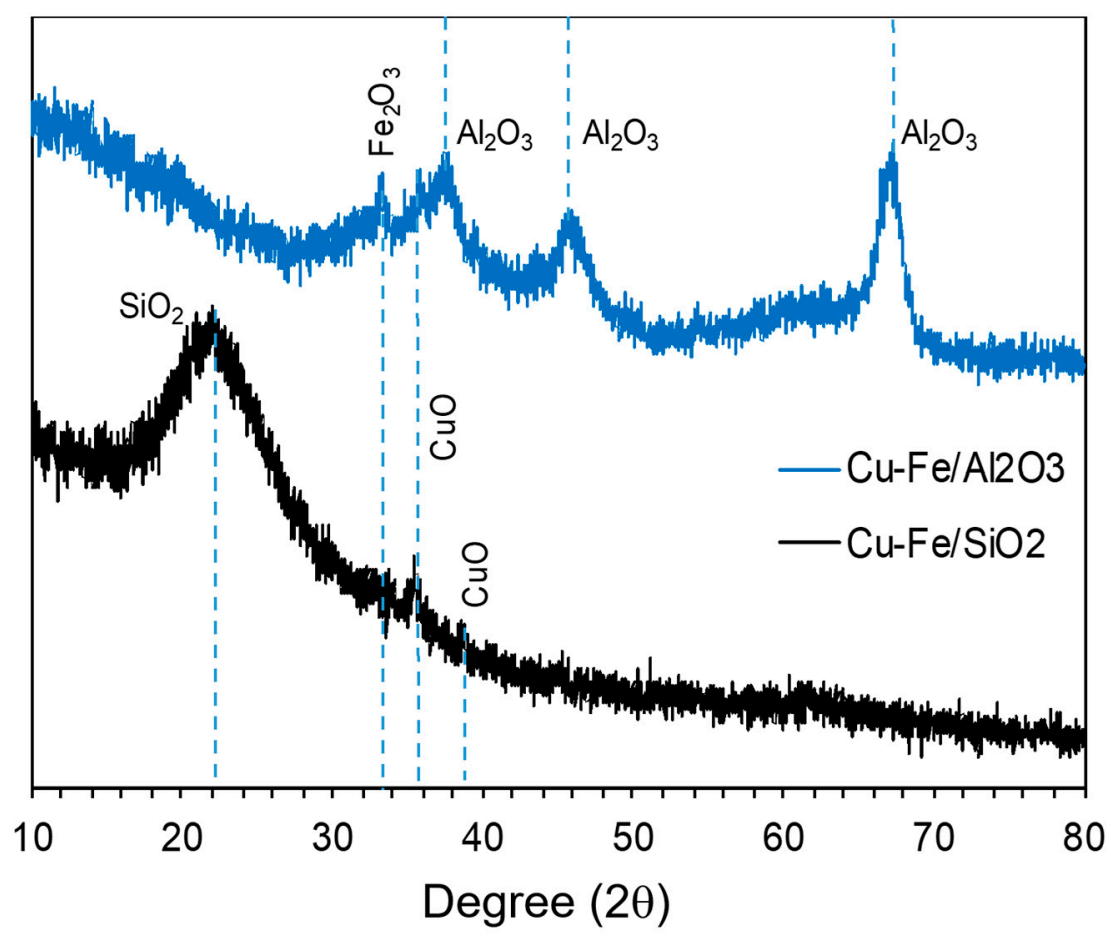

Figure 4. XRD patterns of heterogeneously $\mathrm{Cu}-\mathrm{Fe} / \mathrm{SiO}_{2}$ and $\mathrm{Cu}-\mathrm{Fe} / \mathrm{Al}_{2} \mathrm{O}_{3}$ mixed metal oxides catalysts.

The quantitative analysis of metal oxides in synthesized catalysts by XRF technique was also reported in Table 1 . After calcination at $350^{\circ} \mathrm{C}$ for $4 \mathrm{~h}$ under excess air, $\mathrm{Cu}: \mathrm{Fe}$ molar ratio of 1:1 from both $\mathrm{Cu}-\mathrm{Fe} / \mathrm{Al}_{2} \mathrm{O}_{3}$ and $\mathrm{Cu}-\mathrm{Fe} / \mathrm{SiO}_{2}$ catalysts remained the same amount as precursor prepared. The results exhibited that the percentages of metal oxides in $\mathrm{Cu}-\mathrm{Fe} / \mathrm{Al}_{2} \mathrm{O}_{3}$ catalyst were $12.80 \% \mathrm{CuO}, 8.15 \% \mathrm{Fe}_{2} \mathrm{O}_{3}, 78.67 \% \mathrm{Al}_{2} \mathrm{O}_{3}$ and $0.07 \% \mathrm{SiO}_{2}$ by weight, while $\mathrm{Cu}-\mathrm{Fe} / \mathrm{SiO}_{2}$ catalyst contained $12.27 \% \mathrm{CuO}, 10.38 \% \mathrm{Fe}_{2} \mathrm{O}_{3}, 0.12 \% \mathrm{Al}_{2} \mathrm{O}_{3}$ and $76.36 \% \mathrm{SiO}_{2}$. Majority of metal oxides from $\mathrm{Cu}$ and $\mathrm{Fe}$ was $\mathrm{CuO}$ or $\mathrm{Cu}^{2+}$ and $\mathrm{Fe}_{2} \mathrm{O}_{3}$ or $\mathrm{Fe}^{3+}$ while $\mathrm{Al}_{2} \mathrm{O}_{3}$ and $\mathrm{SiO}_{2}$ support remained the same phase as initial form. The XRF results of all catalysts and supports were corresponded with XRD pattern from Figure 4.

Table 1. The percentage of metal oxides in heterogeneously $\mathrm{Cu}-\mathrm{Fe} / \mathrm{Al}_{2} \mathrm{O}_{3}, \mathrm{Cu}-\mathrm{Fe} / \mathrm{SiO}_{2}$ mixed metal oxides catalysts and $\mathrm{SiO}_{2}, \mathrm{Al}_{2} \mathrm{O}_{3}$ supports analyzed by $\mathrm{X}$-ray Fluorescence Spectrometry (XRF).

\begin{tabular}{ccccc}
\hline \multirow{2}{*}{ Element (wt\%) } & \multicolumn{4}{c}{ Catalyst } \\
\cline { 2 - 5 } & $\mathbf{C u}-\mathbf{F e} / \mathbf{A l}_{\mathbf{2}} \mathbf{O}_{\mathbf{3}}$ & $\mathbf{C u}-\mathbf{F e} / \mathbf{S i O} \mathbf{O}_{\mathbf{2}}$ & $\mathbf{A l}_{\mathbf{2}} \mathbf{O}_{\mathbf{3}}$ & $\mathbf{S i O}_{\mathbf{2}}$ \\
\hline $\mathrm{CuO}$ & 12.80 & 12.27 & nd & nd \\
$\mathrm{Fe}_{2} \mathrm{O}_{3}$ & 8.15 & 10.38 & 0.02 & 0.05 \\
$\mathrm{Al}_{2} \mathrm{O}_{3}$ & 78.67 & 0.12 & 99.57 & 0.15 \\
$\mathrm{SiO}_{2}$ & 0.07 & 76.36 & 0.12 & 98.54 \\
Others & 0.31 & 0.87 & 0.29 & 1.26 \\
\hline
\end{tabular}

nd = not detected.

3.2.2. X-ray Photoelectron Spectroscopy (XPS) of Heterogeneously Mixed Metal Oxides Catalysts

To understand more insights into the oxidation state of $\mathrm{Fe}$ and $\mathrm{Cu}$ species in synthesized mixed metal oxide catalyst, the overall XPS analysis of $\mathrm{Cu}$ and $\mathrm{Fe}$ on $\mathrm{Al}_{2} \mathrm{O}_{3}$ and $\mathrm{SiO}_{2}$ support was performed as shown in Figure 5A,D. Chemical surface state of catalysts contained majority of $\mathrm{O} 1 \mathrm{~s}, \mathrm{Cu} 2 \mathrm{p}$, and Fe $2 \mathrm{p}$ for the active species as well as $\mathrm{Al} 2 \mathrm{p}$ and $\mathrm{Si}$ $2 p$ for the support according to the precursors. For $\mathrm{Cu}-\mathrm{Fe} / \mathrm{Al}_{2} \mathrm{O}_{3}$ catalyst, $\mathrm{Fe} 2 \mathrm{p}_{1 / 2}$ and $\mathrm{Fe}$ $2 p_{3 / 2}$ spinning orbit peaks were illustrated in Figure $5 B$. The Fe $2 p_{3 / 2}$ peaks represented 
$\mathrm{Fe}^{3+}$ and $\mathrm{Fe}^{2+}$ species were detected at binding energy of 712.4 and $710.3 \mathrm{eV}$ attributed to the presence of $\mathrm{Fe}_{2} \mathrm{O}_{3}$ and $\mathrm{FeO}$, respectively, while the satellite vibration peak of $\mathrm{Fe}$ was observed at $717.9 \mathrm{eV}[49,50]$. The peak intensity in XPS analysis suggested that the binding energy of $\mathrm{FeO}$ was slightly lower than $\mathrm{Fe}_{2} \mathrm{O}_{3}$, and the oxidized $\mathrm{FeO}$ could generate $\mathrm{Fe}_{2} \mathrm{O}_{3}$ during calcination process in excess of air.
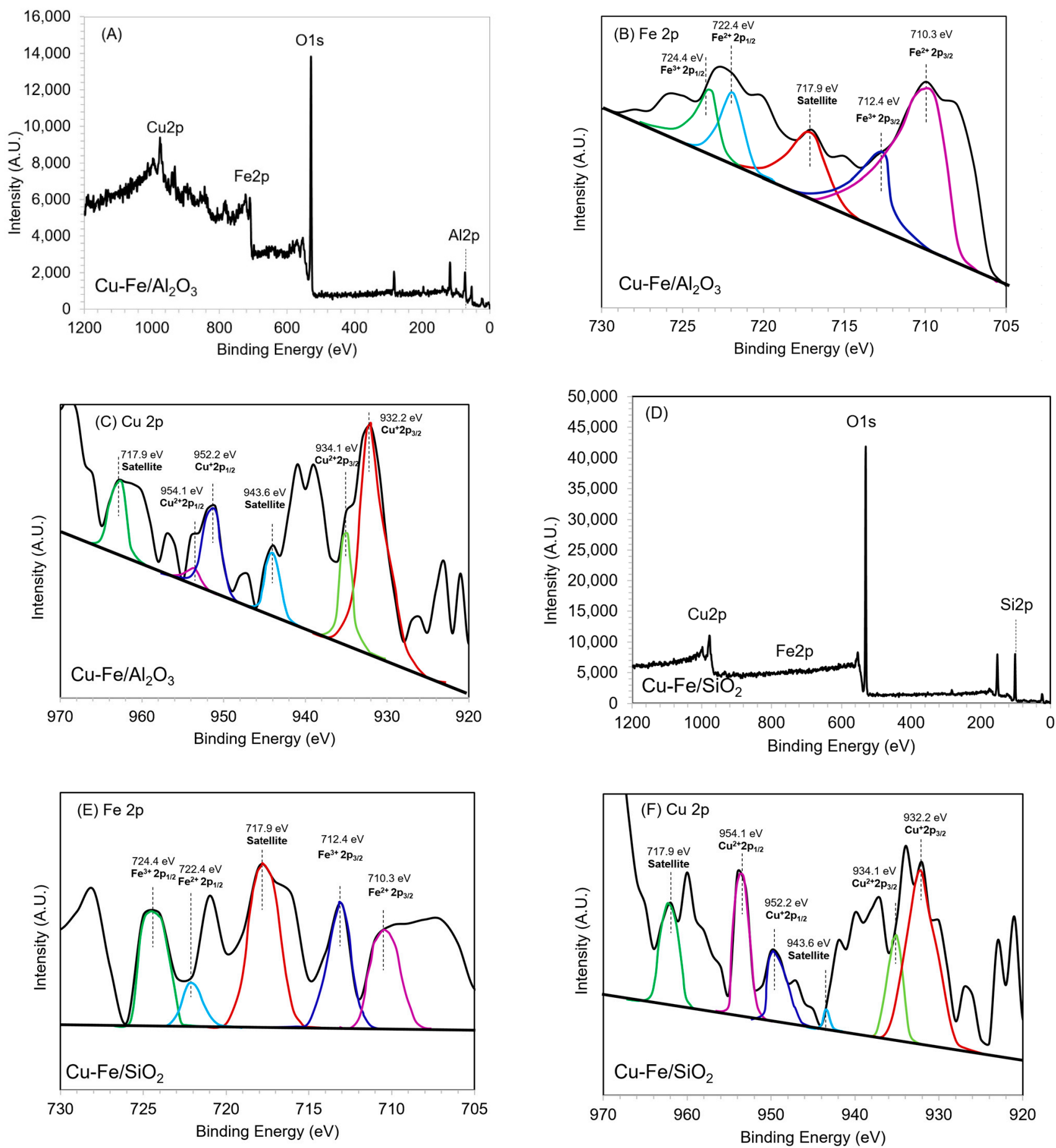

Figure 5. XPS spectra recorded for (A) overall spectrum, (B) Fe 2p, (C) $\mathrm{Cu} 2 \mathrm{p}$ of $\mathrm{Cu}-\mathrm{Fe} / \mathrm{Al}_{2} \mathrm{O}_{3}$ catalyst, and (D) overall spectrum, (E) Fe $2 \mathrm{p}$ and (F) $\mathrm{Cu} 2 \mathrm{p}$ of $\mathrm{Cu}-\mathrm{Fe} / \mathrm{SiO}_{2}$ catalyst.

In case of copper species, the XPS spectra showed the predominantly spinning orbit peaks for $\mathrm{Cu} 2 \mathrm{p}_{3 / 2}$ and $\mathrm{Cu} 2 \mathrm{p}_{1 / 2}$ corresponding to the binding energy values at 934 
and $954.1 \mathrm{eV}$, respectively. This was in good concordance with the result in previous literature [51-53]. $\mathrm{Cu} 2 \mathrm{p}_{3 / 2}$ XPS peaks of $\mathrm{Cu}^{2+}$ and $\mathrm{Cu}^{+}$species indicating the presence of $\mathrm{CuO}$ and $\mathrm{Cu}_{2} \mathrm{O}$ after calcination process were prominent at binding energy of 934.1 and $932.2 \mathrm{eV}$, respectively (Figure $5 \mathrm{C}$ ). $\mathrm{CuO} / \mathrm{Cu}_{2} \mathrm{O}$ oxygen carriers are the higher oxygen transport capacity and higher reactivity [54], thus it is suitable for facilitating oxidative depolymerization of lignin. The shake-up satellite peak of $\mathrm{Cu}$ at $943.6 \mathrm{eV}$ was observed which was well corresponded to a previous work [55]. Moreover, the down shifted XPS peak from 934 to $932 \mathrm{eV}$ referred to the $\mathrm{Cu}^{2+}$ ion on catalyst surface concentration while metallic $\mathrm{Cu}^{0}$ was not obviously detected in $\mathrm{Cu}-\mathrm{Fe} / \mathrm{Al}_{2} \mathrm{O}_{3}$ and $\mathrm{Cu}-\mathrm{Fe} / \mathrm{SiO}_{2}$ catalysts. It has also been observed that $\mathrm{Cu}$ oxides do not react with the $\mathrm{SiO}_{2}$ and have the high reactivity and oxygen transport capacity [56]. The oxidation state and electron vacancy of Fe and $\mathrm{Cu}$ on catalyst surface substantially influences the catalytic pathway of lignin depolymerization to phenolic compounds. Similar results were found for $\mathrm{Cu}-\mathrm{Fe} / \mathrm{SiO}_{2}$ (Figure 5D-F); however, when compared with $\mathrm{Al}_{2} \mathrm{O}_{3}$ support, $\mathrm{Fe}^{2+}$ species attributed to $\mathrm{FeO}$ were less intense compared to $\mathrm{Fe}^{3+}$ assigned to $\mathrm{Fe}_{2} \mathrm{O}_{3}$. This was confirmed by XRF results demonstrated in Table 1. Since the oxidation state of iron species is $\mathrm{Fe}_{1-\mathrm{x}} \mathrm{O} \rightarrow \mathrm{Fe}_{3} \mathrm{O}_{4} \rightarrow \mathrm{Fe}_{2} \mathrm{O}_{3}$ [57], the depletion of oxygen during calcination from the trade-off between copper and iron species possibly causes the presence of mixed $\mathrm{FeO} / \mathrm{Fe}_{2} \mathrm{O}_{3}$ and $\mathrm{Cu}_{2} \mathrm{O} / \mathrm{CuO}$ as shown in XPS peaks. This occurrence may facilitate the greater acid state of $\mathrm{Cu}-\mathrm{Fe} / \mathrm{Al}_{2} \mathrm{O}_{3}$ and more basic state of $\mathrm{Cu}-\mathrm{Fe} / \mathrm{SiO}_{2}$ which could be characterized by $\mathrm{NH}_{3}-\mathrm{TPD}$ analysis.

\subsection{3. $\mathrm{NH}_{3}$-TPD Analysis of Synthesized Catalysts}

Variation of temperature from low to high levels in $\mathrm{NH}_{3}$ adsorption-desorption process was performed to analyze the strength of acidity in the synthesized catalyst. As illustrated in Figure $\mathrm{S} 1$, the peak appeared in the temperature range from $150{ }^{\circ} \mathrm{C}$ to $200^{\circ} \mathrm{C}$ found in $\mathrm{Cu}$ $\mathrm{Fe} / \mathrm{Al}_{2} \mathrm{O}_{3}, \mathrm{Al}_{2} \mathrm{O}_{3}, \mathrm{Cu}-\mathrm{Fe} / \mathrm{SiO}_{2}$ and $\mathrm{SiO}_{2}$ indicated the weak acid sites or weak interaction of ammonia with copper and iron oxides as well as the $\mathrm{Al}_{2} \mathrm{O}_{3}$ and $\mathrm{SiO}_{2}$ supports. This peak at low temperature was ascribed to weakly bound ammonia onto the catalysts whereas the peak at higher temperature corresponds to ammonia specifically adsorbed onto the acid sites. It has been previously reported that very strong acid sites $\left(\mathrm{h}^{+}\right.$-peak) were found between $550{ }^{\circ} \mathrm{C}$ to $700{ }^{\circ} \mathrm{C}$ [58] which were considerably found in $\mathrm{Cu}-\mathrm{Fe} / \mathrm{SiO}_{2}$, and $\mathrm{SiO}_{2}$ indicating very strong acid sites in the catalysts.

For $\mathrm{NH}_{3}-\mathrm{TPD}$ analysis, the peak position gives information about the relative acid strength while the width of the peak provides evidence of the distribution of the strength under identical experimental conditions. To calculate the binding strength of the acid sites, a theoretical model is an effective tool when slow diffusion as the rate-limiting step has to be excluded $[59,60]$ and the total acid sites could be quantified by the integration of peak area from $\mathrm{NH}_{3}$-TPD chromatograms. As shown in Table S1, the total acid site density of synthesized catalysts and the supports was calculated based on the absorption and desorption of ammonia when the temperature range was 100 and $700{ }^{\circ} \mathrm{C}$ (Figure S1). Comparing at the same dry weight of materials, the addition of metal oxides, $\mathrm{Cu}\left(\mathrm{NO}_{3}\right)_{2}$ and $\left(\mathrm{Fe}\left(\mathrm{NO}_{3}\right)_{3}\right)$ as precursors, by doping into the $\mathrm{Al}_{2} \mathrm{O}_{3}$ and $\mathrm{SiO}_{2}$ supports significantly decreased the acid site density as shown in Table S1.

3.2.4. Field Emission Scanning Electron Microscopy with Energy-Dispersive X-ray Spectroscopy (FESEM-EDX) Mapping of Heterogeneously Mixed Metal Oxides Catalysts

The morphological and surface elemental composition of heterogeneously mixed metal oxides $\mathrm{Cu}-\mathrm{Fe} / \mathrm{SiO}_{2}$ and $\mathrm{Cu}-\mathrm{Fe} / \mathrm{Al}_{2} \mathrm{O}_{3}$ catalysts were analyzed with field emission scanning electron microscopy with energy dispersive X-ray spectroscopy (FESEM-EDX) as illustrated in Figure 6 and Figures S2 and S3. The EDX mapping analysis showed the similar pattern of $\mathrm{Cu}$ and $\mathrm{Fe}$ ions from co-impregnation that were well dispersed on $\mathrm{Al}_{2} \mathrm{O}_{3}$ and $\mathrm{SiO}_{2}$ supports. The surface elemental analysis results showed the presence of $\mathrm{Cu}$ and $\mathrm{Fe}$ on $\mathrm{Al}_{2} \mathrm{O}_{3}$ and $\mathrm{SiO}_{2}$ support accordingly as demonstrated in Tables $\mathrm{S} 2$ and $\mathrm{S} 3$, respectively. Therefore, the co-impregnation technique for mixed metal oxides catalyst synthesis was suitable to form the metal oxide catalysts on the support without either agglomeration 
or growth of metal crystal cluster. The morphology of the synthesized $\mathrm{Cu}-\mathrm{Fe} / \mathrm{Al}_{2} \mathrm{O}_{3}$ and $\mathrm{Cu}-\mathrm{Fe} / \mathrm{SiO}_{2}$ catalysts after $\mathrm{Cu}$ and $\mathrm{Fe}$ impregnation was analyzed by scanning electron microscopic (SEM) technique as illustrated in Figure $\mathrm{S} 4$. $\mathrm{The}^{\mathrm{SiO}}{ }_{2}$ support was the finest particle with 1000 magnification and having 5-20 $\mu \mathrm{m}$ in particle size.
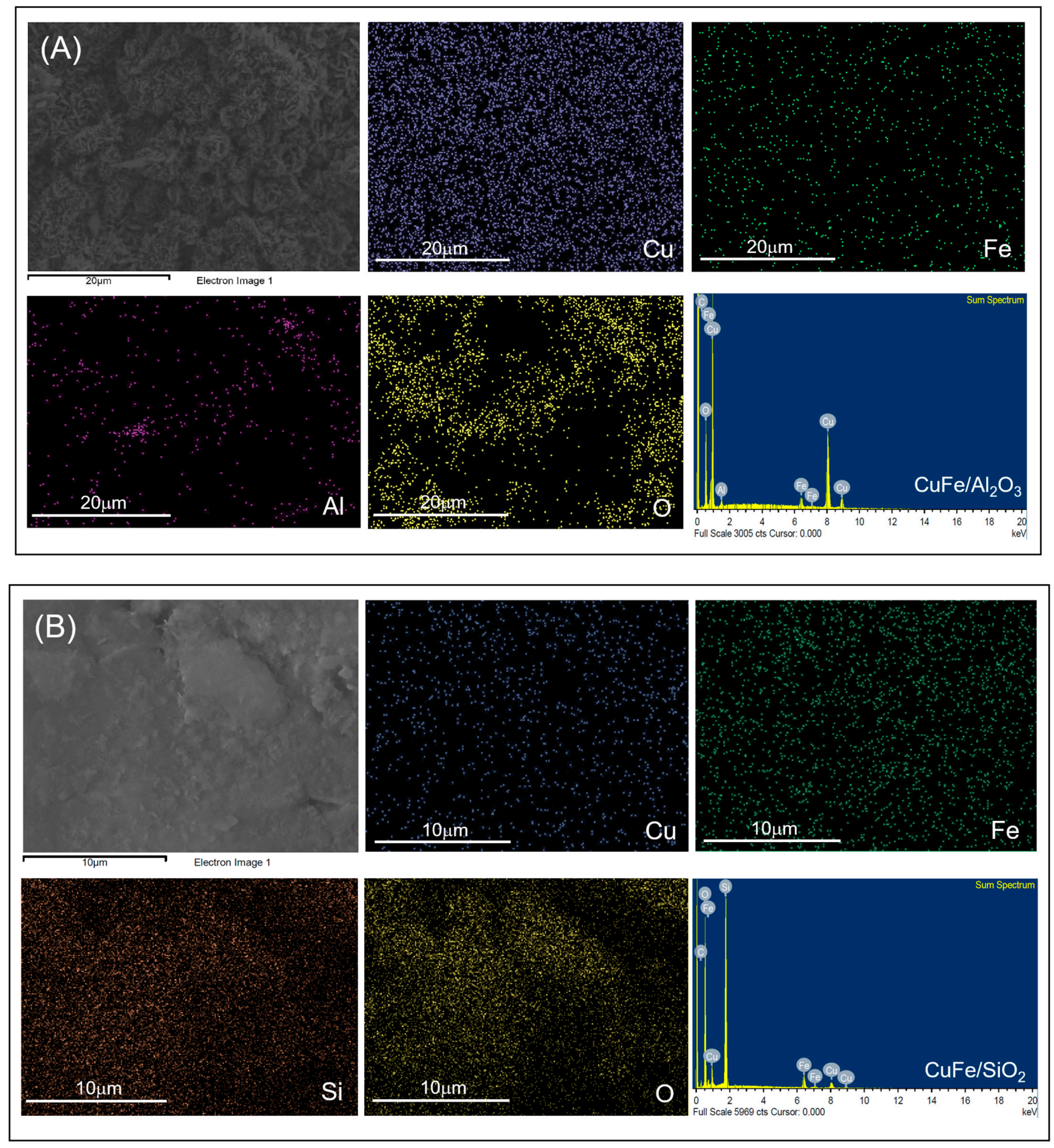

Figure 6. FESEM-EDX elemental mapping of (A) $\mathrm{Cu}-\mathrm{Fe} / \mathrm{Al}_{2} \mathrm{O}_{3}$ and (B) $\mathrm{Cu}-\mathrm{Fe} / \mathrm{SiO}_{2}$ catalysts. 


\subsection{Phenolic Compounds Production from $\mathrm{K}_{2} \mathrm{CO}_{3}$-Lignin and $\mathrm{NaOH}$-Lignin with Heterogeneously Mixed Metal Oxides Catalysts}

After the synthesis of heterogeneously mixed metal oxides catalysts, they were used for microwave-assisted hydrothermal depolymerization of $\mathrm{K}_{2} \mathrm{CO}_{3}$-lignin and $\mathrm{NaOH}$-lignin to produce phenolic compounds. From the previous experiment, the optimal condition for homogeneous lignin depolymerization to specific products was the microwave-assisted reaction catalyzed by $\mathrm{Cu}(\mathrm{OH})_{2}+\mathrm{Fe}_{2} \mathrm{O}_{3}$ co-catalyst at $300 \mathrm{~W}$ for 15 and $30 \mathrm{~min}$ with $1 \mathrm{wt} \%$ of $\mathrm{H}_{2} \mathrm{O}_{2}$ [26]. Thus, for the present experiment on heterogeneous lignin depolymerization using mixed metal oxides catalyst, the aforementioned optimal condition was selected and the reaction took place for 15 and $30 \mathrm{~min}$ for both $\mathrm{K}_{2} \mathrm{CO}_{3}$-lignin and $\mathrm{NaOH}$-lignin.

From the GC-MS analysis, the percentage of phenolic compound concentration was summarized in Table 2. The highest percentage of total phenolic compound concentration of $63.87 \mathrm{wt} \%$ was obtained from microwave-assisted oxidative degradation of $\mathrm{K}_{2} \mathrm{CO}_{3}$ lignin when the lignin degradation reaction was at $300 \mathrm{~W}, 30 \mathrm{~min}$ with $1.0 \mathrm{wt} \% \mathrm{H}_{2} \mathrm{O}_{2}$ and catalyzed by $\mathrm{Cu}-\mathrm{Fe} / \mathrm{SiO}_{2}$ catalyst. The main products from aforementioned condition contained $19.21 \mathrm{wt} \%$ of syringol, $2.16 \mathrm{wt} \%$ of vanillin, $3.69 \mathrm{wt} \%$ of acetovanillone, $2.16 \mathrm{wt} \%$ of syringaldehyde, $9.36 \mathrm{wt} \%$ of acetosyringone and $27.29 \mathrm{wt} \%$ of 2,4-di-tert-butylphenol (Figures S5 and S6). In case of NaOH-lignin, the highest percentage of phenolic compound concentration was $49.52 \mathrm{wt} \%$. The major products included $27.06 \mathrm{wt} \%$ of syringol, $1.61 \mathrm{wt} \%$ of vanillin, $4.39 \mathrm{wt} \%$ of acetovanillone, $1.97 \mathrm{wt} \%$ of syringaldehyde, $11.71 \mathrm{wt} \%$ of acetosyringone and $13.09 \mathrm{wt} \%$ of 2,4-di-tert-butylphenol when the lignin depolymerization reaction was conducted with $1.0 \mathrm{wt} \% \mathrm{H}_{2} \mathrm{O}_{2}$ and $\mathrm{Cu}-\mathrm{Fe} / \mathrm{Al}_{2} \mathrm{O}_{3}$ catalyst for $30 \mathrm{~min}$ (Figures $\mathrm{S} 7$ and $\mathrm{S} 8$ ). Although $\mathrm{Cu}-\mathrm{Fe} / \mathrm{SiO}_{2}$ catalyzed the $\mathrm{K}_{2} \mathrm{CO}_{3}$-lignin depolymerization provided greater total phenolic products, lower selectivities of main products i.e., syringol and acetosyringone were obtained compared with $\mathrm{CuFe} / \mathrm{Al}_{2} \mathrm{O}_{3}$ catalyzed the $\mathrm{NaOH}$-lignin depolymerization (Table 2).

For $\mathrm{K}_{2} \mathrm{CO}_{3}$-lignin, the $\mathrm{Cu}-\mathrm{Fe} / \mathrm{SiO}_{2}$ catalyst showed the higher performance and greater selectivity for total phenolic compound production compared with $\mathrm{Cu}-\mathrm{Fe} / \mathrm{Al}_{2} \mathrm{O}_{3}$ catalyst. Although, $\mathrm{Cu}-\mathrm{Fe} / \mathrm{Al}_{2} \mathrm{O}_{3}$ catalyst surface contained $8.15 \mathrm{wt} \% \mathrm{Fe}_{2} \mathrm{O}_{3}$ and $12.80 \mathrm{wt} \% \mathrm{CuO}$ similar to $10.38 \mathrm{wt} \% \mathrm{Fe}_{2} \mathrm{O}_{3}$ and $12.27 \mathrm{wt} \% \mathrm{CuO}$ in $\mathrm{Cu}-\mathrm{Fe} / \mathrm{SiO}_{2}$ catalyst (Table 1), nevertheless, the smaller particle size of $\mathrm{Cu}-\mathrm{Fe} / \mathrm{SiO}_{2}$ catalyst analyzed by SEM images (Figure S4) as well as lower acid site density of $\mathrm{Cu}-\mathrm{Fe} / \mathrm{SiO}_{2}$ catalyst compared with that of $\mathrm{Cu}-\mathrm{Fe} / \mathrm{Al}_{2} \mathrm{O}_{3}$ catalyst (Table S1) substantially promoted the depolymerization of $\mathrm{K}_{2} \mathrm{CO}_{3}$-lignin. From gel permeation chromatography (GPC) results, the $\mathrm{K}_{2} \mathrm{CO}_{3}$-lignin had smaller molecular weight lignin relative to $\mathrm{NaOH}$-lignin [26] and thus particular 2,4-di-tert-butylphenol were selectively generated as the main product (Tables S4 and S5).

In contrast, $\mathrm{NaOH}$-lignin exhibited the greatest amount of syringol and acetosyringone when using $\mathrm{Cu}-\mathrm{Fe} / \mathrm{Al}_{2} \mathrm{O}_{3}$ as the catalyst from 30-min depolymerization reaction. This was possibly due to the higher molecular weight of $\mathrm{NaOH}$-lignin required stronger acidity of $\mathrm{Cu}-\mathrm{Fe} / \mathrm{Al}_{2} \mathrm{O}_{3}$ catalyst to facilitate the lignin depolymerization (Table S1). From the results when the oxidative depolymerization took place for $30 \mathrm{~min}, \mathrm{Cu}-\mathrm{Fe} / \mathrm{Al}_{2} \mathrm{O}_{3}$ catalyst exhibited higher selectivity on lignin conversion to both syringol and acetosyringone compared with $\mathrm{Cu}-\mathrm{Fe} / \mathrm{SiO}_{2}$ catalyst. Although, the total phenolic compound from $\mathrm{Cu}-\mathrm{Fe} / \mathrm{Al}_{2} \mathrm{O}_{3}$ catalyst (49.52 $\mathrm{wt} \%$ ) was lower compared with that from $\mathrm{Cu}-\mathrm{Fe} / \mathrm{SiO}_{2}$ catalyst $(63.87 \mathrm{wt} \%)$, the higher syringol yield from $\mathrm{Cu}-\mathrm{Fe} / \mathrm{Al}_{2} \mathrm{O}_{3}$ catalyst $(27.07 \mathrm{wt} \%)$ was achieved compared with that from $\mathrm{Cu}-\mathrm{Fe} / \mathrm{SiO}_{2}$ catalyst (19.21 wt $\%$ ). These corresponded to $54.64 \%$ and $30.08 \%$ selectivity from $\mathrm{Cu}-\mathrm{Fe} / \mathrm{Al}_{2} \mathrm{O}_{3}$ and $\mathrm{Cu}-\mathrm{Fe} / \mathrm{SiO}_{2}$ catalyst, respectively as demonstrated in Tables 2, S6 and S7. 


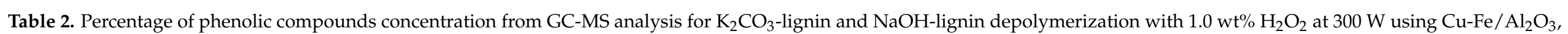
$\mathrm{Cu}-\mathrm{Fe} / \mathrm{SiO}_{2}$, and without catalyst.

\begin{tabular}{|c|c|c|c|c|c|c|c|c|c|c|c|c|c|}
\hline \multirow[b]{2}{*}{$\begin{array}{l}\text { Type of } \\
\text { Reaction }\end{array}$} & \multirow[b]{2}{*}{$\begin{array}{l}\text { Alkaline EFB } \\
\text { Extracted } \\
\text { Lignin }\end{array}$} & \multirow[b]{2}{*}{ Catalyst } & \multicolumn{6}{|c|}{ Main Products (wt \%) } & \multirow[b]{2}{*}{$\begin{array}{c}\text { Total } \\
\text { Phenolic } \\
\text { Compounds } \\
(\mathbf{w t} \%)\end{array}$} & \multicolumn{3}{|c|}{ \%Selectivity } & \multirow[b]{2}{*}{ Ref. } \\
\hline & & & $\underset{\text { Syringol }}{\text { Syl }}$ & Vanillin & $\begin{array}{c}\text { Aceto- } \\
\text { Vanillone } \\
\mathrm{O}_{2} \mathrm{CH}_{3}\end{array}$ & $\begin{array}{c}\text { 2,4-Di-tert } \\
\text { Butylphenol }\end{array}$ & $\begin{array}{l}\text { Syringal- } \\
\text { Dehyde }\end{array}$ & $\begin{array}{c}\text { Aceto } \\
\text { Syringone } \\
{ }^{\circ} \mathrm{CH}_{3}\end{array}$ & & Syringol & $\begin{array}{l}\text { 2,4-Di-tert } \\
\text { Butylphenol }\end{array}$ & Acetosyringone & \\
\hline \multirow{13}{*}{$\begin{array}{l}\text { Heterogeneous } \\
\text { reaction }^{\text {a }}\end{array}$} & \multicolumn{13}{|c|}{$15 \mathrm{~min}$} \\
\hline & \multirow{3}{*}{$\mathrm{K}_{2} \mathrm{CO}_{3}$-lignin } & $\mathrm{Cu}-\mathrm{Fe} / \mathrm{Al}_{2} \mathrm{O}_{3}$ & 7.71 & - & 0.63 & 23.19 & - & 0.64 & 32.17 & 23.97 & 72.09 & 1.99 & This study \\
\hline & & $\mathrm{Cu}-\mathrm{Fe} / \mathrm{SiO}_{2}$ & 6.94 & - & 1.08 & 24.39 & - & 0.95 & 33.36 & 20.80 & 73.11 & 2.85 & This study \\
\hline & & No Catalyst & 4.89 & 0.97 & 2.40 & 20.71 & - & 2.80 & 31.77 & 15.39 & 65.19 & 8.81 & This study \\
\hline & \multirow{3}{*}{$\mathrm{NaOH}$-lignin } & $\mathrm{Cu}-\mathrm{Fe} / \mathrm{Al}_{2} \mathrm{O}_{3}$ & 13.78 & 0.45 & 2.13 & 20.98 & 0.68 & 4.71 & 42.73 & 32.25 & 49.10 & 11.02 & This study \\
\hline & & $\mathrm{Cu}-\mathrm{Fe} / \mathrm{SiO}_{2}$ & 10.07 & 0.41 & 1.60 & 20.02 & 0.87 & 4.33 & 37.30 & 27.00 & 53.67 & 11.61 & This study \\
\hline & & No Catalyst & 5.14 & 1.19 & 2.76 & 2.76 & 0.65 & 7.12 & 19.62 & 26.20 & 14.07 & 36.29 & This study \\
\hline & \multicolumn{13}{|c|}{$30 \mathrm{~min}$} \\
\hline & \multirow{3}{*}{$\mathrm{K}_{2} \mathrm{CO}_{3}$-lignin } & $\mathrm{Cu}-\mathrm{Fe} / \mathrm{Al}_{2} \mathrm{O}_{3}$ & 13.39 & 1.39 & 2.33 & 20.17 & 0.98 & 4.72 & 42.98 & 31.15 & 46.93 & 10.98 & This study \\
\hline & & $\mathrm{Cu}-\mathrm{Fe} / \mathrm{SiO}_{2}$ & 19.21 & 2.16 & 3.69 & 27.29 & 2.16 & 9.36 & 63.87 & 30.08 & 42.73 & 14.65 & This study \\
\hline & & No Catalyst & 5.86 & 1.00 & 2.84 & 13.09 & 0.77 & 6.39 & 29.95 & 19.57 & 66.89 & 21.34 & This study \\
\hline & \multirow[t]{2}{*}{$\mathrm{NaOH}$-lignin } & $\mathrm{Cu}-\mathrm{Fe} / \mathrm{SiO}_{2}$ & 13.52 & 1.25 & 2.74 & 2.29 & 1.48 & 7.56 & 28.84 & 46.88 & 7.94 & 26.21 & This study \\
\hline & & No Catalyst & 10.34 & 1.35 & 4.7 & 1.27 & 0.79 & 10.28 & 28.73 & 35.99 & 4.42 & 35.78 & This study \\
\hline \multirow{6}{*}{$\begin{array}{l}\text { Homogeneous } \\
\text { reaction }^{\mathrm{b}}\end{array}$} & \multicolumn{13}{|c|}{$15 \mathrm{~min}$} \\
\hline & $\mathrm{K}_{2} \mathrm{CO}_{3}$-lignin & $\mathrm{Cu}(\mathrm{OH})_{2}+\mathrm{Fe}_{2} \mathrm{O}_{3}$ & 50.33 & 3.24 & 10.72 & - & 4.96 & 20.48 & 89.73 & 56.09 & - & 22.82 & [26] \\
\hline & NaOH-lignin & $\mathrm{Cu}(\mathrm{OH})_{2}+\mathrm{Fe}_{2} \mathrm{O}_{3}$ & 28.11 & 1.39 & 4.22 & - & 3.36 & 7.55 & 44.63 & 62.98 & - & 16.92 & [26] \\
\hline & \multicolumn{13}{|c|}{$30 \mathrm{~min}$} \\
\hline & $\mathrm{K}_{2} \mathrm{CO}_{3}$-lignin & $\mathrm{Cu}(\mathrm{OH})_{2}+\mathrm{Fe}_{2} \mathrm{O}_{3}$ & 44.77 & 4.00 & 10.15 & - & 6.66 & 22.52 & 88.1 & 50.82 & - & 25.56 & [26] \\
\hline & $\mathrm{NaOH}$-lignin & $\mathrm{Cu}(\mathrm{OH})_{2}+\mathrm{Fe}_{2} \mathrm{O}_{3}$ & 52.51 & 3.89 & 8.23 & - & 4.84 & 19.58 & 89.05 & 58.97 & - & 21.99 & [26] \\
\hline
\end{tabular}

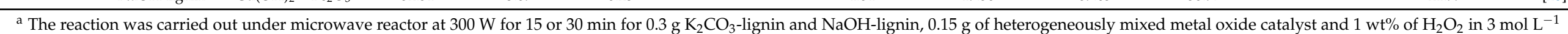

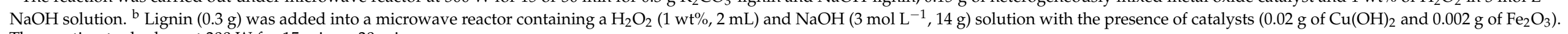

The reaction took place at $300 \mathrm{~W}$ for $15 \mathrm{~min}$ or $30 \mathrm{~min}$. 
From the main products of lignin depolymerization from NaOH-lignin from EFB i.e., syringol and acetosyringone, similar results were reported for $\mathrm{NaOH}$ depolymerized lignin, which contained an increased phenolic hydroxyl group, active protons at $\mathrm{C} 5$, and an enhanced methoxyl group twice as much as that of original lignin [45]. In case of $\mathrm{K}_{2} \mathrm{CO}_{3}$ lignin, $65-67 \%$ selectivity of 2,4-Di-tert butylphenol was achieved as the main product for the system without catalyst for both $15 \mathrm{~min}$ and $30 \mathrm{~min}$ of alkaline depolymerization (Table 2). The findings were in good agreement with a previous report in which alkali carbonates influenced a decrease of proton concentration during depolymerization reaction and led to enhancing parallel and secondary reaction mechanisms to generate more phenols and conjugated phenolic compounds from demethylation of original lignin [46].

Table 2 additionally demonstrated the comparison of yield and selectivity of main products from lignin depolymerization, especially syringol and acetosyringone. The findings revealed that homogeneous catalytic depolymerization of EFB lignin by $\mathrm{Cu}(\mathrm{OH})_{2}$ $+\mathrm{Fe}_{2} \mathrm{O}_{3}$ gave higher yield and selectivity relative to heterogeneous catalysis. However, similar trends were observed for both homogeneous and heterogeneous depolymerization when highest syringol + acetosyringone yields were achieved when using $15 \mathrm{~min}$ of depolymerization for $\mathrm{K}_{2} \mathrm{CO}_{3}$-lignin ( $50.33 \mathrm{wt} \%$ of syringol and $20.48 \mathrm{wt} \%$ of acetosyringone) and $30 \mathrm{~min}$ depolymerization for $\mathrm{NaOH}-$ lignin $(52.51 \mathrm{wt} \%$ of syringol and $29.58 \mathrm{wt} \%$ of acetosyringone). Both conditions provided remarkably high selectivity. Lower selectivity of phenolic compound production indicates that more side reaction products were obtained in the experiments of heterogeneously mixed metal oxides catalysts compared with homogeneous mixed metal oxides catalysts in our previous study [26]. It was observed from GC-MS analysis that when the reaction time was increased from $15 \mathrm{~min}$ to $30 \mathrm{~min}$, higher concentration of carboxylic acids and quinone such as benzoic acid and acetic acid were generated Figures S5 and S8.

As demonstrated in Figure 7, it was obvious that $\mathrm{NaOH}$-lignin from EFB gave higher yield of S-lignin which was mainly syringol and acetosyringone at $15 \mathrm{~min}$ of reaction compared with $\mathrm{K}_{2} \mathrm{CO}_{3}$-lignin (Figure $7 \mathrm{~A}$ ), and $\mathrm{Cu}-\mathrm{Fe} / \mathrm{Al}_{2} \mathrm{O}_{3}$ catalyst markedly facilitated the generation of syringol product over $\mathrm{Cu}-\mathrm{Fe} / \mathrm{SiO}_{2}$ and without catalyst. For the microwave reaction at $30 \mathrm{~min}$, syringol and acetosyringone yields from $\mathrm{NaOH}$-lignin polymerization over $\mathrm{Cu}-\mathrm{Fe} / \mathrm{Al}_{2} \mathrm{O}_{3}$ and $\mathrm{Cu}-\mathrm{Fe} / \mathrm{SiO}_{2}$ catalysts were substantially enhanced as shown in Figure 7B. This was possibly due to either enhanced hydrogenolysis of $\beta-\mathrm{O}-4$ ether linkages within lignin precursor or oxidative cleavage of $\mathrm{C}-\mathrm{O}-\mathrm{C}$ under microwave heating over metal catalysts i.e., $\mathrm{Fe}$, $\mathrm{Rh}$ which markedly yield S-type lignin relatively to guaiacyl or G-type lignin as main products $[13,42]$. Another tentative mechanism was oxidative C-O-C break down and demethylation at $C_{\alpha}$ and $C_{5}$ of 2,4-di-tert-butylphenol yielding syringol as a main product.

When considering the yield and selectivity of the main products, Figure $8 \mathrm{~A}-\mathrm{C}$ shows the correlation between the different alkaline extraction methods and the role of heterogeneous catalysts used in the subsequent depolymerization step. In case of syringol production, the depolymerization reaction of $\mathrm{NaOH}$-lignin using $\mathrm{Cu}-\mathrm{Fe} / \mathrm{Al}_{2} \mathrm{O}_{3}$ catalyst provided the greatest syringol yield $(27.06 \mathrm{wt} \%)$ and selectivity $(54.64 \%)$ from the microwave reaction at $300 \mathrm{~W}$ for $30 \mathrm{~min}$ as illustrated in Figure 8A. The reason was possibly owing to higher acidity and $\mathrm{Fe}_{2} \mathrm{O}_{3}$ content of $\mathrm{Cu}-\mathrm{Fe} / \mathrm{Al}_{2} \mathrm{O}_{3}$ catalyst compared with $\mathrm{Cu}-\mathrm{Fe} / \mathrm{SiO}_{2}$ catalyst (Tables 1 and $\mathrm{S} 1$ ). For production of acetosyringone, $\mathrm{NaOH}$-lignin was the suitable substrate for microwave-assisted depolymerization and the highest monophenolics yield at 10.28 $\mathrm{wt} \%$ and selectivity at $35.78 \%$ were achieved from the reaction at $300 \mathrm{~W}$ for $30 \mathrm{~min}$ without adding catalyst (Figure 8B). Therefore, mild oxidative reaction using $\mathrm{H}_{2} \mathrm{O}_{2}$ without catalyst was the most optimal condition for acetosyringone production from $\mathrm{NaOH}$-lignin. In case of 2,4-Di-tert butylphenol production (Figure 8C), the highest yield from 23.19-24.39 wt $\%$ and selectivity from $72.09-73.11 \%$ were obtained from $\mathrm{K}_{2} \mathrm{CO}_{3}$-lignin and successive lignin depolymerization over $\mathrm{Cu}-\mathrm{Fe} / \mathrm{SiO}_{2}$ and $\mathrm{Cu}-\mathrm{Fe} / \mathrm{Al}_{2} \mathrm{O}_{3}$ catalysts at $300 \mathrm{~W}$ for only $15 \mathrm{~min}$. An increase of microwave reaction duration from $15 \mathrm{~min}$ to $30 \mathrm{~min}$ gave adverse effect on both yield and selectivity of 2,4-Di-tert butylphenol. The results confirmed that the 
$\mathrm{K}_{2} \mathrm{CO}_{3}$-lignin had smaller molecular weight lignin relative to $\mathrm{NaOH}$-lignin [26] and thus particular 2,4-Di-tert butylphenol was selectively generated as the main products in a very short period of reaction ( $15 \mathrm{~min}$ ) over $\mathrm{Cu}-\mathrm{Fe} / \mathrm{SiO}_{2}$ and $\mathrm{Cu}-\mathrm{Fe} / \mathrm{Al}_{2} \mathrm{O}_{3}$ catalysts.

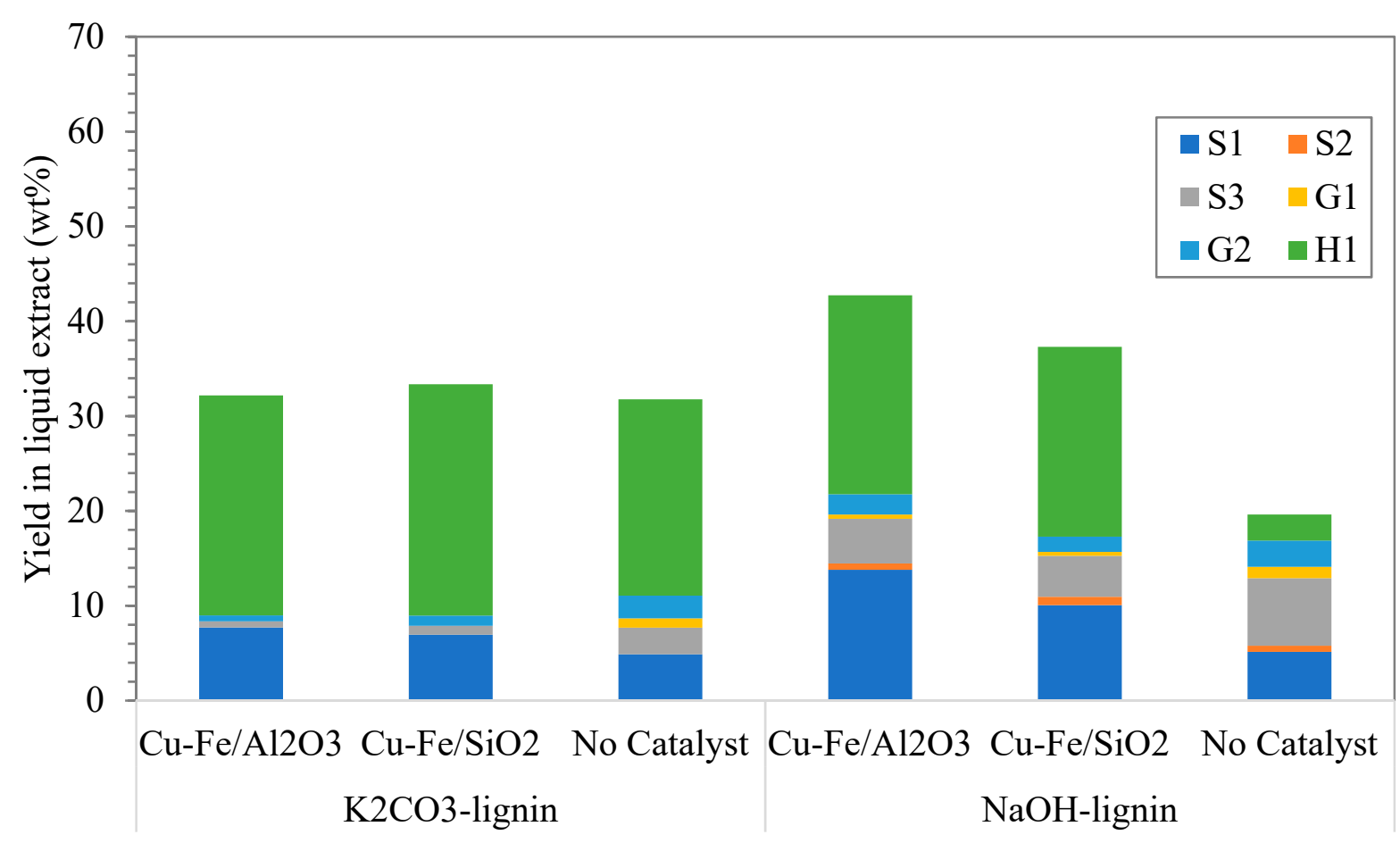

(A)

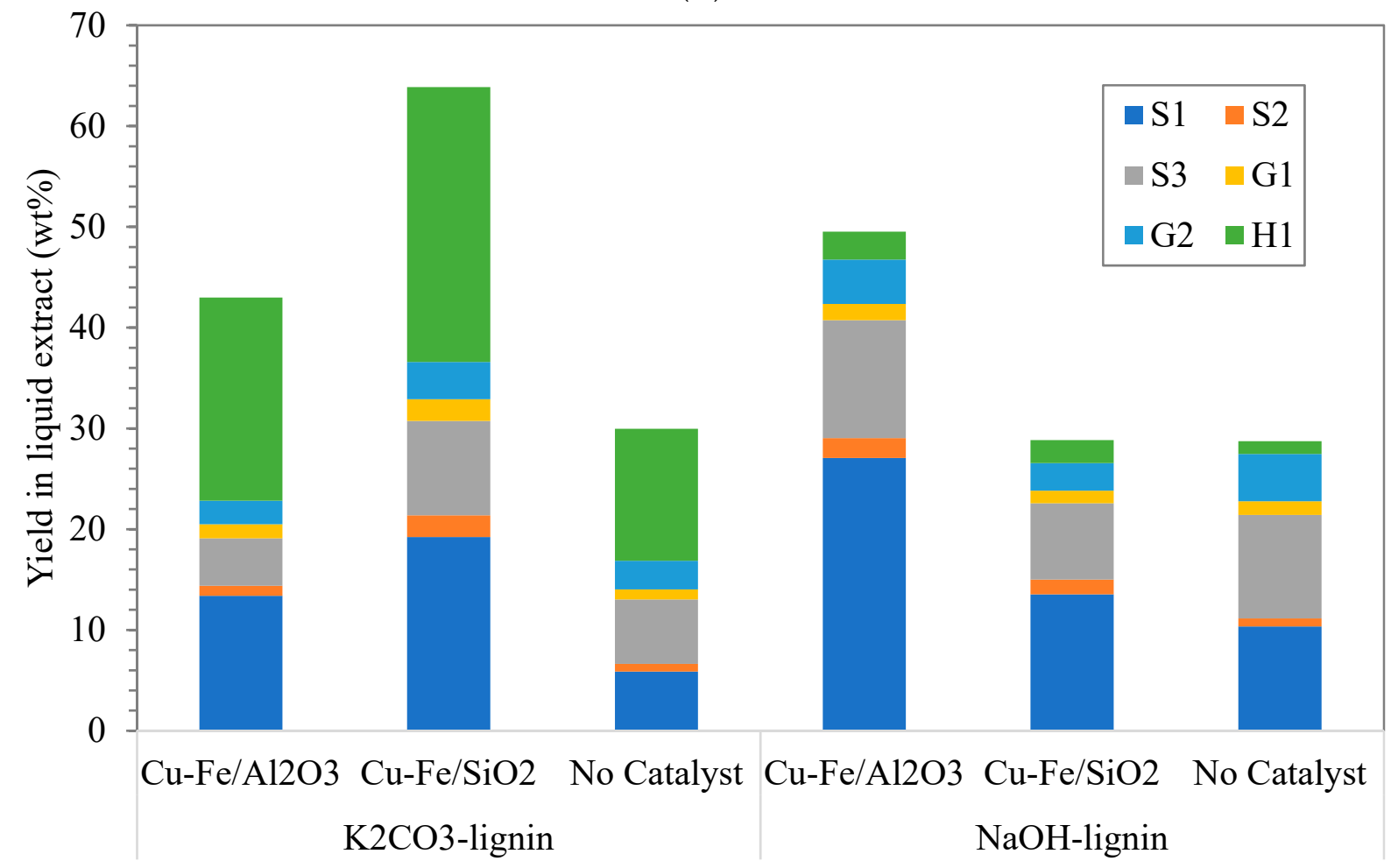

(B)

Figure 7. Lignin monomer yield in liquid product from depolymerization of $\mathrm{K}_{2} \mathrm{CO}_{3}$-lignin and $\mathrm{NaOH}$-lignin under microwave heating at $300 \mathrm{~W}$ for (A) $15 \mathrm{~min}$, and (B) 30 min over heterogeneous catalysts namely $\mathrm{Cu}-\mathrm{Fe} / \mathrm{Al}_{2} \mathrm{O}_{3}, \mathrm{Cu}-\mathrm{Fe} / \mathrm{SiO} 2$ and without catalyst; S1 = Syringol, S2 = Syringaldehyde, S3 = Acetosyringone, G1 = Vanillin, G2 = Acetovanilone, and $\mathrm{H} 1$ = 2,4-Di-tert butylphenol. 

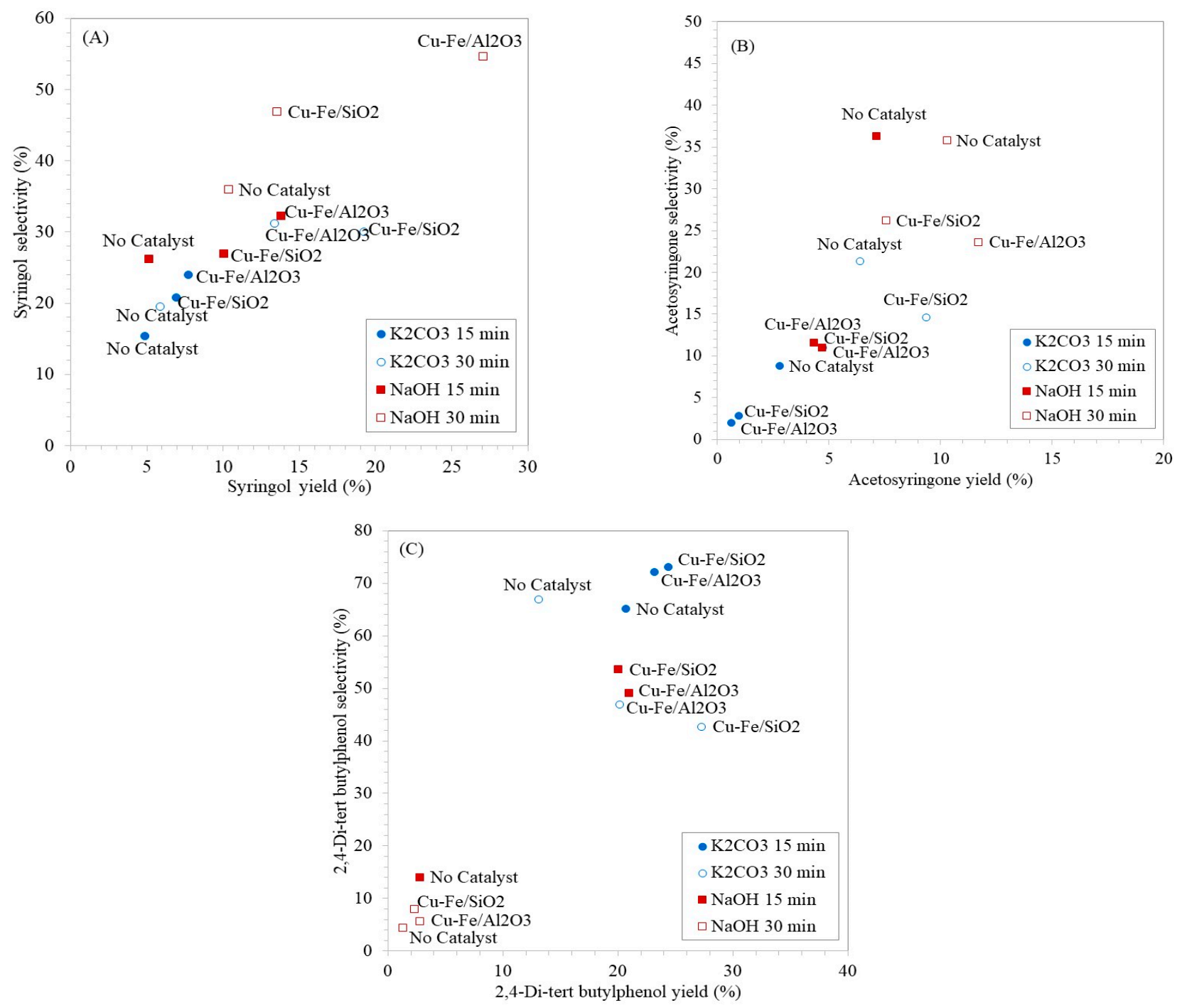

Figure 8. Yield and selectivity from the depolymerization of EFB derived alkaline lignin $\left(\mathrm{K}_{2} \mathrm{CO}_{3}\right.$-lignin and $\mathrm{NaOH}$-lignin) to (A) syringol, (B) acetosyringone and (C) 2,4-di-tert butylphenol using $300 \mathrm{~W}$ microwave reaction for 15 and $30 \mathrm{~min}$ over different catalysts.

As shown in Figures 7 and 8, $\mathrm{CuFe} / \mathrm{Al}_{2} \mathrm{O}_{3}$ exhibited greater performance on both yield and selectivity toward syringol and acetosyringone, which were the main products of EFB lignin in this system. The synergistic effect of $\mathrm{Cu}$ and Fe was found to favor the reactivity of the catalyst. The results were confirmed by greater monophenolic yield and selectivity of the products. The present system gave superior phenolic yields compared with other previous work on lignin depolymerization, for example $17.92 \mathrm{wt} \%$ monophenolic compound from $\mathrm{CuO} / \mathrm{Fe}_{2}\left(\mathrm{SO}_{4}\right)_{3} / \mathrm{NaOH}$ catalyst [61], less than $35 \mathrm{wt} \%$ monophenolic yield from $\mathrm{CuSO}_{4}$ and $\mathrm{LaMn}_{0.8} \mathrm{Cu}_{0.2} \mathrm{O}_{3}$ catalysts [34].

From recyclability study, the amount of main products from fresh and spent catalysts was quantified using standard curve (Figure S9). The results from Figure 9A showed that the presence of $\mathrm{Fe}$ and $\mathrm{Cu}$ on $\mathrm{Al}_{2} \mathrm{O}_{3}$ support from $\mathrm{CuFe} / \mathrm{Al}_{2} \mathrm{O}_{3}$ catalyst favored to produce high yield of syringaldehyde from $\mathrm{NaOH}$-lignin in the 1st reaction in which fresh catalyst was used. However, the 2nd and 3rd reaction of spent catalyst gave minimal yield of syringaldehyde in a respective degree (Table S8) due to the leaching of $\mathrm{Cu}$ and Fe respectively as demonstrated in XPS analysis results for Fe2p and $\mathrm{Cu} 2 \mathrm{p}$ of spent $\mathrm{CuFe} / \mathrm{Al}_{2} \mathrm{O}_{3}$ catalyst in Figure 10A. After $\mathrm{Cu}$ and $\mathrm{Fe}$ leaching, acidity of $\mathrm{Al}_{2} \mathrm{O}_{3}$ support seemingly enhanced 
the yield of acetosyringone, vanillin, and acetovanillone. Similar to $\mathrm{CuFe} / \mathrm{SiO}_{2}$ catalyst, fresh catalyst was prone to selectively generate acetosyringone and syringaldehyde as demonstrated in Figure 9B. The spent $\mathrm{CuFe} / \mathrm{SiO}_{2}$ catalyst was found to lose $\mathrm{Cu}$ and $\mathrm{Fe}$ respectively during the second time of recyclability test (Figure 10B), therefore the effect of $\mathrm{SiO}_{2}$ support was found to favor vanillin, acetosyringone, syringol, and acetovanillone as $\mathrm{NaOH}$-lignin depolymerization products in a respective degree. $\mathrm{SiO}_{2}$ support exhibited no effect on generation of syringaldehyde and (2,4-Di-tert butylphenol) without $\mathrm{Cu}$ and Fe doping.

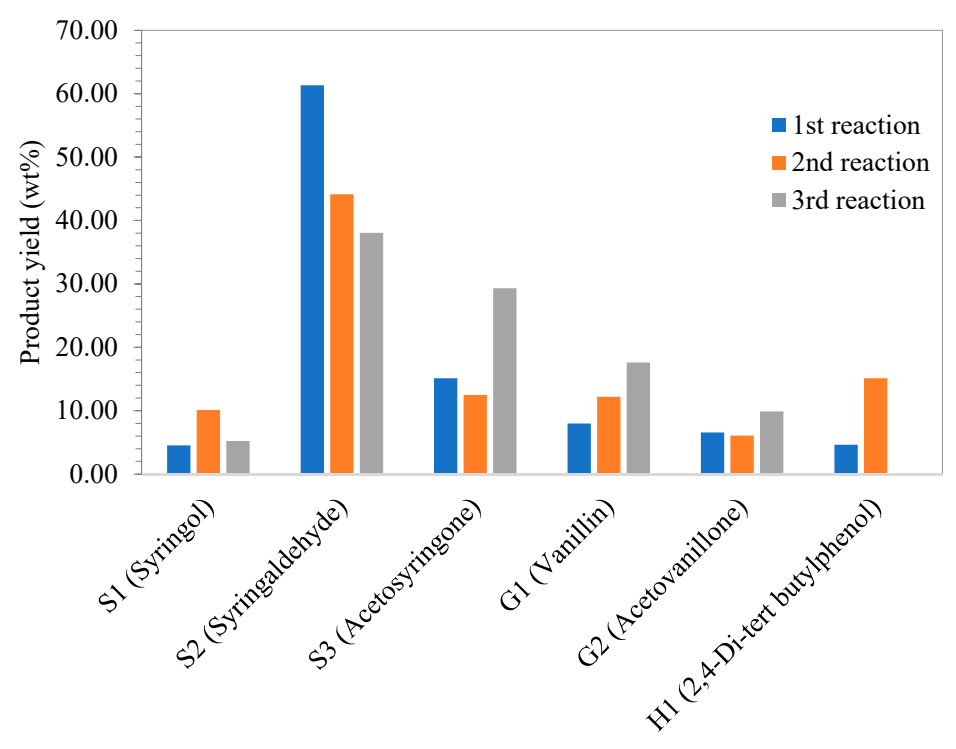

(A)

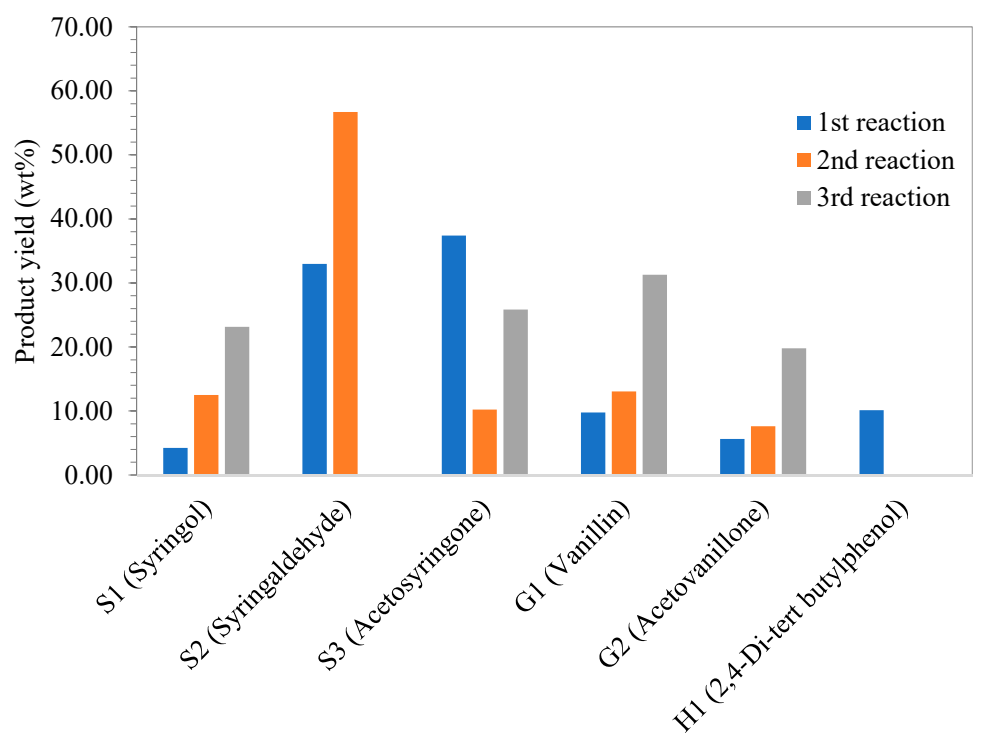

(B)

Figure 9. Product yield from the recyclability study of (A) $\mathrm{CuFe} / \mathrm{Al}_{2} \mathrm{O}_{3}$, and (B) $\mathrm{CuFe} / \mathrm{SiO}_{2}$ catalysts on depolymerization of $\mathrm{NaOH}$-lignin under microwave at $300 \mathrm{~W}$ for $30 \mathrm{~min}$. 


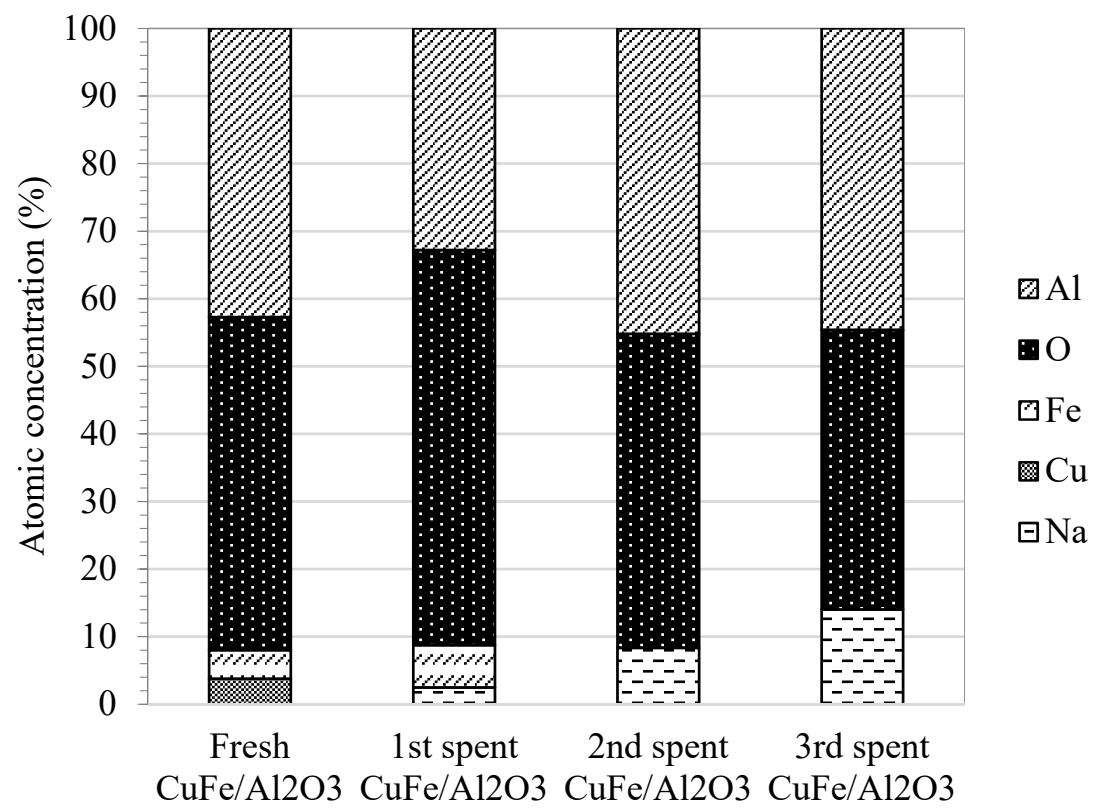

(A)

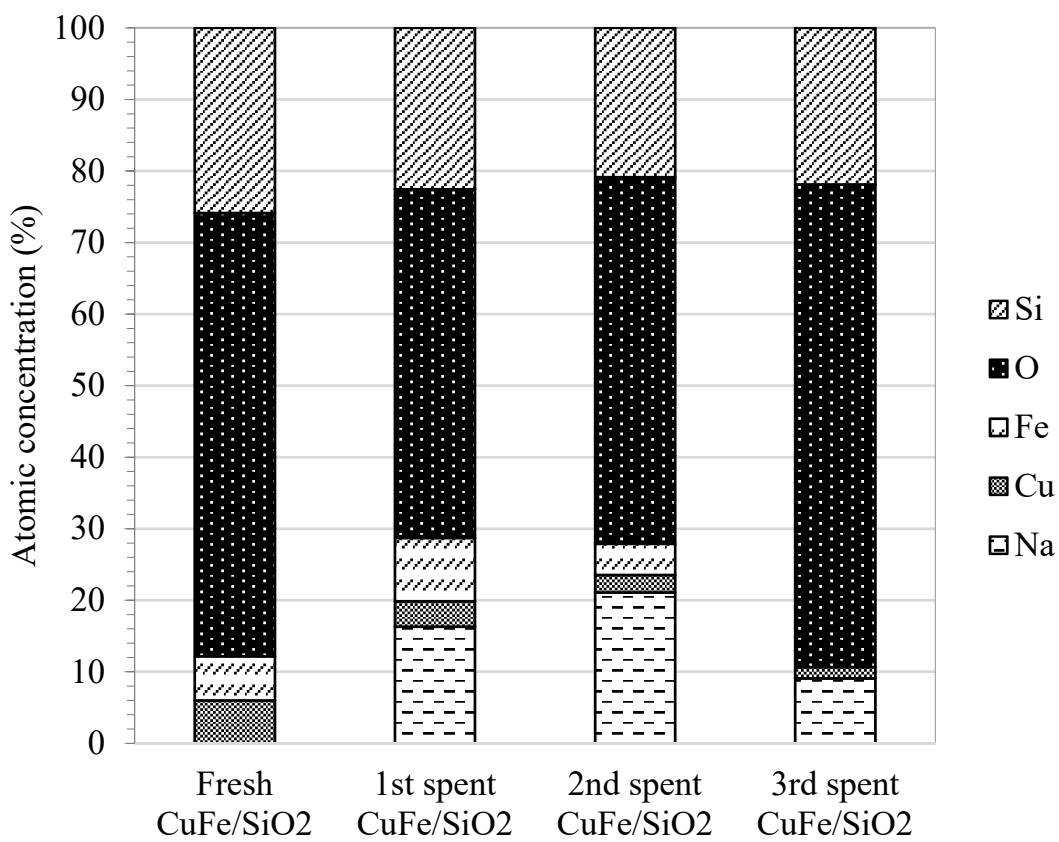

(B)

Figure 10. Atomic concentration of fresh and spent catalysts (A) $\mathrm{CuFe} / \mathrm{Al}_{2} \mathrm{O}_{3}$ and (B) $\mathrm{CuFe} / \mathrm{SiO}_{2}$ from recyclability study of heterogeneous catalyst on $\mathrm{NaOH}$-lignin depolymerization under microwave heating at $300 \mathrm{~W}$ for $30 \mathrm{~min}$.

3.4. The Proposed Mechanism of Oxidative Depolymerization of EFB Derived Lignin with Mixed Metal Oxides Cu-Fe Catalyst

The results of the present experiments were consistent with a previous report of $\mathrm{Ma}$ and coworkers [32] who reported that catalysts of $\mathrm{Cu}$ (II), Fe (III), and Mn (II, III) played an important role in catalysis of oxidation reaction of lignin structure in the presence of oxygen or peroxide $\left(\mathrm{H}_{2} \mathrm{O}_{2}\right)$. By breaking down the $\beta-\mathrm{O}-4$ bonds in the lignin structure via oxidative and hydrolysis reaction, the lignin structure was depolymerized to monophenolic compounds such as vanillin, syringaldehyde or $p$-hydrobenzaldehyde. Similarly, 
Ouyang studied the $\mathrm{Cu}$ (II) and $\mathrm{Fe}(\mathrm{III})$ catalyzed reactions in alkaline solution for lignin depolymerization that were able to produce a high yield of phenolic compounds [61]. It was postulated that the oxidation of lignin structure does not only cleave the $\beta-\mathrm{O}-4$ or $\mathrm{C}-\mathrm{C}$ bonds in lignin, but also breaks down the structure of the aromatic ring resulting in smaller phenolic monomers such as phenol and benzoic acid. It additionally produced by-products including quinones and dicarboxylic acid groups such as formic acid, acetic acid and butanoic acid by ring-opening reactions (Figures S3-S6).

EFB lignin contains a substantial fraction of sinapyl units, which can be observed from syringol derivatives after oxidative depolymerization. From the results, syringaldehyde, acetosyringone, acetovanillone, and vanillin were the major products formed during lignin depolymerization. The lignin oxidative degradation results indicate that the transformation mechanism of lignin could generate oligomers, and subsequent phenolic compounds involving a free radical pathway that initiates cleavage of alkyl-aryl ether ( $\alpha-\mathrm{O}-4$ and $\beta-\mathrm{O}-4)$, aryl-aryl ether (4-O-5) and aryl-aryl (5-5) bonds, hydrogen abstraction and $\beta$-scission reactions, which is in good agreement with previous work [62]. It was found that similar products were detected from lignin depolymerization via pyrolysis and UV radiation. It can be implied that thermal energy is the main driving force for the aforementioned bond fission reactions in thermolysis, while UV radiation augments the bond cleavage in photocatalysis. In the present study, microwave radiation and the reactive radical species such as $\bullet \mathrm{OH}$ and $\mathrm{O}_{2} \bullet{ }^{-}$radicals from $\mathrm{H}_{2} \mathrm{O}_{2}$ dissociation induce these reactions to occur. Importantly, hydroxyl radicals can react with benzene ring via electrophilic addition and cause the cleavage of $\alpha-\mathrm{O}-4$ or $\beta-\mathrm{O}-4$ ether links in lignin [63]. As a result, $\mathrm{OH}$ group substitution is achieved. Moreover, the previous research reported that the formation of dimethoxy benzoquinone was earlier proposed to occur by the action of singlet oxygen $\left({ }^{1} \mathrm{O}_{2}\right)$ or superoxide radicals $\left(\mathrm{O}_{2} \bullet^{-}\right)$on the phenolic ring, which results in the cleavage of the bond between aromatic and the $\alpha$-carbon [63]. Solely the effect of either $\mathrm{Cu}$ or Fe did not influence the improvement of the reaction, but the combination effect of bimetallic $\mathrm{Cu}$-Fe catalyst. This was confirmed by the findings from a previous work demonstrating that $\mathrm{Fe}_{2} \mathrm{O}_{3} / \gamma-\mathrm{Al}_{2} \mathrm{O}_{3}$ catalyst provided similar lignin degradation product and yield similar with the blank test. The $\mathrm{Fe}_{2} \mathrm{O}_{3} / \gamma-\mathrm{Al}_{2} \mathrm{O}_{3}$ catalyst did not show good activity in the lignin oxidation reaction [64].

The aforementioned phenomena were found to give superior catalytic performance from the synergistic effect of bimetallic $\mathrm{Cu}$ and $\mathrm{Fe}$, especially on $\mathrm{Al}_{2} \mathrm{O}_{3}$ support. It has been observed that the oxygen space will be enhanced with the partial replacement of $\mathrm{Fe}^{3+}$ by $\mathrm{Cu}^{2+}$, according to the previous report [65], which would accelerate the oxygen surface absorption ability of the catalyst and the intermediate content of $\mathrm{O}_{2}-\mathrm{Fe}^{3+}$-lignin complex will be enhanced [66]. They act as oxygen carriers that can attack the lignin [67]. Moreover, the amount of activated species $\mathrm{Cu}^{2}+\mathrm{O}_{2}{ }^{-}$will be increased with the partial replacement of $\mathrm{Fe}^{3+}$ by $\mathrm{Cu}^{2+}$, which will result in a cycling of $\mathrm{Cu}^{2+} / \mathrm{Cu}^{+}\left(\mathrm{Cu}^{2+} \rightarrow \mathrm{Cu}^{+} \rightarrow \mathrm{Cu}^{2}\right.$ $\left.+\mathrm{O}_{2}{ }^{-} \rightarrow \mathrm{Cu}^{2+}\right)$ and $\mathrm{Fe}^{3+} / \mathrm{Fe}^{2+}$ [23]. The proposed mechanism was in good accordance with XPS (Fe2p and $\mathrm{Cu} 2 \mathrm{p}$ ) and XRF results, which indicated the presence of $\mathrm{CuO} / \mathrm{Cu}_{2} \mathrm{O}$ and $\mathrm{Fe}_{2} \mathrm{O}_{3} / \mathrm{FeO}$, respectively. This cycling accelerates the generation of the intermediate quinone methide radicals [68]. Moreover, the intermediate reduction potential of $\mathrm{Cu}^{2+}$ found in alkaline condition $\left(-0.16 \mathrm{~V}\right.$ for the $\mathrm{CuO} / \mathrm{Cu}_{2} \mathrm{O}$ redox pair at $\left.\mathrm{pH} 14\right)$ was postulated to be satisfactory for oxidation of lignin to aldehydes with limited subsequent oxidation of aldehydes [27]. With all the combined effect of the above mentioned factors, the catalytic activity of $\mathrm{CuFe} / \mathrm{Al}_{2} \mathrm{O}_{3}$ is improved.

The role of catalyst support was proved in the recyclability study. The previous study revealed that relatively more acidic $\gamma-\mathrm{Al}_{2} \mathrm{O}_{3}$ support showed better catalyst performance than $\mathrm{CeO}_{2}$ or $\mathrm{TiO}_{2}$ to generate vanillin from lignin depolymerization [30,64]. As a result, in the present study, $\mathrm{SiO}_{2}$ had higher acidity than $\mathrm{Al}_{2} \mathrm{O}_{3}$, and therefore played a vital role to enhance the conversion of guaiacyl lignin (G-lignin) to form acetovanillone and vanillin relatively to $\mathrm{Al}_{2} \mathrm{O}_{3}$ as demonstrated in Figure 9 for the $3 \mathrm{rd}$ reaction when $\mathrm{Cu}$ and $\mathrm{Fe}$ were leached out. In the case of $\mathrm{SiO}_{2}$ support, it was additionally postulated that 
$\mathrm{H}_{2} \mathrm{O}_{2}$ decomposition formed reactive oxygen species and are then physisorbed on silica framework trapped on the hydroxyl network, and eventually transferred to the secondary carbon on the side chain. Consequently, oxidation to such secondary carbon converts it to a more stable carbonyl group of acetovanillone. Further oxidation could yield vanillin as the final product. As shown in Figure 9B, the $3 \mathrm{rd}$ spent $\mathrm{CuFe} / \mathrm{SiO}_{2}$ catalyst with the leaching of $\mathrm{Cu}$ and Fe indicated by decreased intensity of XPS (Cu2p and Fe2p) could significantly change the reaction pathway to more selectively generate acetovanillone and vanillin. The reason was confirmed by a previous study on lignin model compound depolymerization using various structure of silica catalyst under microwave irradiation [69] revealing that surface hydroxyl groups, which in turn facilitate the adsorption of 4-hydroxy-3-methoxyalpha-methyl benzylalcohol or apocynol leading to high conversion to acetovanillone in the systems. Similar result was observed in the case of $\mathrm{Al}_{2} \mathrm{O}_{3}$ support. After $\mathrm{Cu}$ and $\mathrm{Fe}$ leaching, effect of acidity of solely $\mathrm{Al}_{2} \mathrm{O}_{3}$ seemingly shifted the selectivity of product from syringaldehyde to acetovanillone and vanillin as demonstrated in Figures 9A and 10A.

From the lignin depolymerization with mixed metal oxides catalyst, the 2,4-di-tertbutylphenol was one of the different major products produced in the reaction mixture. This has been shown to occur during lignin degradation by mixed metal oxide catalysts typically containing aluminum $\left(\mathrm{Al}_{2} \mathrm{O}_{3}\right)$ and silicon $\left(\mathrm{SiO}_{2}\right)$ as active sites for promoting chemical reactions [70]. However, their reactivity to breakdown inter-unit linkages remains to be proven. It has been revealed that under mild oxidative lignin depolymerization, the side-chain hydroxyl groups were oxidized to carbonyl groups, and after that the reaction is quenched. This conceivably provides a highly selective lignin oxidative modification and warrants further investigation [32,70]. Based on the previous study, mixed $\mathrm{Cu}-\mathrm{Fe}$ oxide catalyst can possibly react with the electronegative hydroxyl groups of $\mathrm{H}_{2} \mathrm{O}_{2}$ and $\mathrm{H}_{2} \mathrm{O}$, and thus remove the hydroxyl group from lignin monomer. The partial hydrogenation of the benzene ring intermediates is postulated, which is favorable to the subsequent dehydroxylation due to the lower bond dissociation energy [71,72]. The intermediate product then reacts with the adsorbed methyl groups, leading to the formation of primitive alkylphenol. The methyl group can be formed from the demethylation step during guaiacol generated during lignin depolymerization [73]. Subsequently, the higher alkylphenols, including tert-butylphenols, iso-propylphenols, and neo-pentylphenols could be formed [74].

\section{Conclusions}

Lignin depolymerization was successfully catalyzed by $\mathrm{Cu}$ (II) and Fe (III) mixed metal oxides catalyst supported on $\mathrm{Al}_{2} \mathrm{O}_{3}$ and $\mathrm{SiO}_{2}$ support. The highest percentage of total phenolic compounds of $63.87 \mathrm{wt} \%$ was obtained from microwave-induced oxidative degradation of $\mathrm{K}_{2} \mathrm{CO}_{3}$-lignin when the lignin depolymerization reaction carried out at $300 \mathrm{~W}, 30 \mathrm{~min}$ with $1.0 \mathrm{wt} \% \mathrm{H}_{2} \mathrm{O}_{2}$ and catalyzed by $\mathrm{Cu}-\mathrm{Fe} / \mathrm{SiO}_{2}$ catalyst. However, when the main products were considered, it contained $19.21 \mathrm{wt} \%$ of syringol corresponding to $30.08 \%$ selectivity. In contrast, the $\mathrm{Cu}-\mathrm{Fe} / \mathrm{Al}_{2} \mathrm{O}_{3}$ catalyst gave lower total phenolic compounds of $49.52 \mathrm{wt} \%$ from $\mathrm{NaOH}$-lignin, but it provided the greatest selectivity of syringol and acetosyrigone at $54.64 \%$ and $23.65 \%$, respectively $(78.29 \%$ total selectivity of two products). Consequently, this optimal condition successfully generated the most favorable value-added chemicals from EFB lignin for utilization as food aroma additives and chemical feedstock.

Supplementary Materials: The following are available online. Table S1: Acidity of synthesized catalysts from $\mathrm{NH}_{3}-\mathrm{TPD}$ analysis, Table S2: The type of element from EDX analysis of $\mathrm{Cu}-\mathrm{Fe} / \mathrm{Al}_{2} \mathrm{O}_{3}$ catalyst, Table S3: The type of element from EDX analysis of $\mathrm{Cu}-\mathrm{Fe} / \mathrm{SiO}_{2}$ catalyst, Table S4: The phenolic compounds peak area percentage from GC-MS analysis for $\mathrm{K}_{2} \mathrm{CO}_{3}$-lignin depolymerization with $\mathrm{Cu}-\mathrm{Fe} / \mathrm{Al}_{2} \mathrm{O}_{3}, \mathrm{Cu}-\mathrm{Fe} / \mathrm{SiO}_{2}$, and without catalyst (microwave heating at 300 watts, $1 \% w / w$ of $\mathrm{H}_{2} \mathrm{O}_{2}$ in $\mathrm{NaOH}$ solution for $15 \mathrm{~min}$ ), Table S5: The phenolic compounds peak area percentage from GC-MS analysis for $\mathrm{K}_{2} \mathrm{CO}_{3}$-lignin depolymerization with $\mathrm{Cu}-\mathrm{Fe} / \mathrm{Al}_{2} \mathrm{O}_{3}, \mathrm{Cu}-\mathrm{Fe} / \mathrm{SiO}_{2}$, and without catalyst (microwave heating at 300 watts, $1 \% w / w$ of $\mathrm{H}_{2} \mathrm{O}_{2}$ in $\mathrm{NaOH}$ solution for $30 \mathrm{~min}$ ), Table S6: The phenolic compounds concentration peak area from GC-MS analysis for NaOH-lignin 
depolymerization with $\mathrm{Cu}-\mathrm{Fe} / \mathrm{Al}_{2} \mathrm{O}_{3}, \mathrm{Cu}-\mathrm{Fe} / \mathrm{SiO}_{2}$, and without catalyst (microwave heating at 300 watts, $1 \% \mathrm{w} / \mathrm{w}$ of $\mathrm{H}_{2} \mathrm{O}_{2}$ in $\mathrm{NaOH}$ solution for $15 \mathrm{~min}$ ), Table S7: The phenolic compounds concentration peak area from GC-MS analysis for $\mathrm{NaOH}$-lignin depolymerization with $\mathrm{Cu}-\mathrm{Fe} / \mathrm{Al}_{2} \mathrm{O}_{3}$, $\mathrm{Cu}-\mathrm{Fe} / \mathrm{SiO}_{2}$ and without catalyst (microwave heating at 300 watts, $1 \% \mathrm{w} / \mathrm{w}$ of $\mathrm{H}_{2} \mathrm{O}_{2}$ in $\mathrm{NaOH}$ solution for $30 \mathrm{~min}$ ); Table S8: Recyclability study of $\mathrm{CuFe} / \mathrm{Al}_{2} \mathrm{O}_{3}$ and $\mathrm{CuFe} / \mathrm{SiO}_{2}$ catalysts on depolymerization of $\mathrm{NaOH}$-lignin under microwave at $300 \mathrm{~W}$ for $30 \mathrm{~min}$; Figure S1: $\mathrm{NH}_{3}-\mathrm{TPD}$ chromatograms of synthesized catalysts and supports of (a) $\mathrm{Cu}-\mathrm{Fe} / \mathrm{Al}_{2} \mathrm{O}_{3}$, (b) $\mathrm{Al}_{2} \mathrm{O}_{3}$, (c) $\mathrm{Cu}-\mathrm{Fe} / \mathrm{SiO}_{2}$, (d) $\mathrm{SiO}_{2}$, Figure S2: The elemental composition of $\mathrm{Cu}-\mathrm{Fe} / \mathrm{Al}_{2} \mathrm{O}_{3}$ mixed metal oxide catalyst from EDX analysis, Figure S3: The elemental composition of $\mathrm{Cu}-\mathrm{Fe} / \mathrm{SiO}_{2}$ mixed metal oxide catalyst from EDX analysis, Figure S4: Morphological of heterogeneous bimetallic and metal organic framework catalysts (a) $\mathrm{Cu}-\mathrm{Fe} / \mathrm{Al}_{2} \mathrm{O}_{3}$ at $\times 500$ magnification (b) $\mathrm{Cu}-\mathrm{Fe} / \mathrm{Al}_{2} \mathrm{O}_{3} \times 1000$ magnification (c) $\mathrm{Cu}$ $\mathrm{Fe} / \mathrm{SiO}_{2}$ at $\times 500$ magnification, and (d) $\mathrm{Cu}-\mathrm{Fe} / \mathrm{SiO}_{2}$ at $\times 2000$ magnification, Figure S5: The phenolic compounds concentration peak area from GC-MS analysis for $\mathrm{K}_{2} \mathrm{CO}_{3}$-lignin depolymerization with $\mathrm{Cu}-\mathrm{Fe} / \mathrm{Al}_{2} \mathrm{O}_{3}, \mathrm{Cu}-\mathrm{Fe} / \mathrm{SiO}_{2}$, and without catalyst (Microwave heating at 300 watts, $1 \% w / w$ of $\mathrm{H}_{2} \mathrm{O}_{2}$ in $\mathrm{NaOH}$ solution for $15 \mathrm{~min}$ ), Figure S6: The phenolic compounds concentration peak area from GC-MS analysis for $\mathrm{K}_{2} \mathrm{CO}_{3}$-lignin depolymerization with $\mathrm{Cu}-\mathrm{Fe} / \mathrm{Al}_{2} \mathrm{O}_{3}, \mathrm{Cu}-\mathrm{Fe} / \mathrm{SiO}$, and without catalyst (microwave heating at 300 watts, $1 \% w / w$ of $\mathrm{H}_{2} \mathrm{O}_{2}$ in $\mathrm{NaOH}$ solution for $30 \mathrm{~min})$, Figure S7: The phenolic compounds concentration peak area from GC-MS analysis for $\mathrm{NaOH}$-lignin depolymerization with $\mathrm{Cu}-\mathrm{Fe} / \mathrm{Al}_{2} \mathrm{O}_{3}, \mathrm{Cu}-\mathrm{Fe} / \mathrm{SiO}_{2}$, and without catalyst (microwave heating at 300 watts, $1 \% w / w$ of $\mathrm{H}_{2} \mathrm{O}_{2}$ in $\mathrm{NaOH}$ solution for $15 \mathrm{~min}$ ), Figure S8: The phenolic compounds concentration peak area from GC-MS analysis for $\mathrm{NaOH}$-lignin depolymerization with $\mathrm{Cu}-\mathrm{Fe} / \mathrm{Al}_{2} \mathrm{O}_{3}, \mathrm{Cu}-\mathrm{Fe} / \mathrm{SiO}_{2}$, and without catalyst (microwave heating at 300 watts, $1 \% w / w$ of $\mathrm{H}_{2} \mathrm{O}_{2}$ in $\mathrm{NaOH}$ solution for $30 \mathrm{~min}$ ), Figure S9: Standard curve from GC analysis of main products of lignin depolymerization for recyclability study.

Author Contributions: Formal analysis, Investigation, Methodology, Writing—original draft, R.P.; Formal analysis, Investigation, A.S.; Visualization, P.P., N.L. and S.R.; Visualization/data presentation, and Validation, B.M.M. and K.C.-W.W.; Conceptualization, Project administration, Supervision, Validation, Writing-review \& editing, C.S. All authors have read and agreed to the published version of the manuscript.

Funding: This research was funded by Thailand Research Fund (TRF) and National Research Council of Thailand (NRCT) grant number RSA6280074. And the APC was funded by Mahidol University.

Institutional Review Board Statement: Not applicable.

Informed Consent Statement: Not applicable.

Acknowledgments: This work was supported by Mid-Career Research Grant (RSA6280074) from Thailand Research Fund (TRF) and National Research Council of Thailand (NRCT). R. Panyadee is thankful for the support from Research and Researchers for Industries (RRi) Research Grant (MSD60I0016) from Thailand Research Fund. N. Laosiripojana was supported by Thailand Research Fund (RTA6280003). K.C.-W. Wu acknowledges the funding supports from Ministry of Science and Technology (MOST), Taiwan (104-2628-E-002-008-MY3; 105-2221-E-002-227-MY3; 105-2218-E-155-007; 105-2221-E-002-003-MY3; 105-2622-E155-003-CC2).

Conflicts of Interest: The authors declare no conflict of interest.

\section{References}

1. Cao, Y.; Chen, S.S.; Zhang, S.; Ok, Y.S.; Matsagar, B.M.; Wu, K.C.W.; Tsang, D.C.W. Advances in lignin valorization towards bio-based chemicals and fuels: Lignin biorefinery. Bioresour. Technol. 2019, 291, 121878. [CrossRef]

2. Cabral Almada, C.; Kazachenko, A.; Fongarland, P.; Da Silva Perez, D.; Kuznetsov, B.N.; Djakovitch, L. Oxidative depolymerization of lignins for producing aromatics: Variation of botanical origin and extraction methods. Biomass Convers. Biorefinery 2020, 2020, 1-14. [CrossRef]

3. Margellou, A.; Triantafyllidis, K.S. Catalytic Transfer Hydrogenolysis Reactions for Lignin Valorization to Fuels and Chemicals. Catalysts 2019, 9, 43. [CrossRef]

4. Muangsuwan, C.; Kriprasertkul, W.; Ratchahat, S.; Liu, C.-G.; Posoknistakul, P.; Laosiripojana, N.; Sakdaronnarong, C. Upgrading of Light Bio-oil from Solvothermolysis Liquefaction of an Oil Palm Empty Fruit Bunch in Glycerol by Catalytic Hydrodeoxygenation Using $\mathrm{NiMo} / \mathrm{Al}_{2} \mathrm{O}_{3}$ or $\mathrm{CoMo} / \mathrm{Al}_{2} \mathrm{O}_{3}$ Catalysts. ACS Omega 2021, 6, 2999-3016. [CrossRef]

5. Albano, G.; Evangelisti, C.; Aronica, L.A. Hydrogenolysis of Benzyl Protected Phenols and Aniline Promoted by Supported Palladium Nanoparticles. ChemistrySelect 2017, 2, 384-388. [CrossRef] 
6. Espro, C.; Gumina, B.; Szumelda, T.; Paone, E.; Mauriello, F. Catalytic Transfer Hydrogenolysis as an Effective Tool for the Reductive Upgrading of Cellulose, Hemicellulose, Lignin, and Their Derived Molecules. Catalysts 2018, 8, 313. [CrossRef]

7. Réti, C.; Casetta, M.; Duquesne, S.; Bourbigot, S.; Delobel, R. Flammability properties of intumescent PLA including starch and lignin. Polym. Adv. Technol. 2008, 19, 628-635. [CrossRef]

8. De Blasio, C.; De Gisi, S.; Molino, A.; Simonetti, M.; Santarelli, M.; Björklund-Sänkiaho, M. Concerning operational aspects in supercritical water gasification of kraft black liquor. Renew. Energy 2019, 130, 891-901. [CrossRef]

9. Wang, S.; Dai, G.; Yang, H.; Luo, Z. Lignocellulosic biomass pyrolysis mechanism: A state-of-the-art review. Prog. Energy Combust. Sci. 2017, 62, 33-86. [CrossRef]

10. Shen, D.K.; Jin, W.; Hu, J.; Xiao, R.; Luo, K.H. An overview on fast pyrolysis of the main constituents in lignocellulosic biomass to valued-added chemicals: Structures, pathways and interactions. Renew. Sustain. Energy Rev. 2015, 51, 761-774. [CrossRef]

11. Liu, C.; Wu, S.; Zhang, H.; Xiao, R. Catalytic oxidation of lignin to valuable biomass-based platform chemicals: A review. Fuel Process. Technol. 2019, 191, 181-201. [CrossRef]

12. Huang, X.; Atay, C.; Zhu, J.; Palstra, S.W.L.; Koranyi, T.I.; Boot, M.D.; Hensen, E.J.M. Catalytic Depolymerization of Lignin and Woody Biomass in Supercritical Ethanol: Influence of Reaction Temperature and Feedstock. ACS Sustain. Chem. Eng. 2017, 5, 10864-10874. [CrossRef] [PubMed]

13. Matsagar, B.M.; Wang, Z.-Y.; Sakdaronnarong, C.; Chen, S.S.; Tsang, D.C.W.; Wu, K.C.-W. Effect of solvent, the role of formic acid and $\mathrm{Rh} / \mathrm{C}$ catalysts for the efficient liquefaction of lignin. ChemCatChem 2019, 11, 4604-4616. [CrossRef]

14. Singh, R.; Prakash, A.; Balagurumurthy, B.; Bhaskar, T. Hydrothermal Liquefaction of Biomass. In Recent Advances in ThermoChemical Conversion of Biomass; Elsevier: Amsterdam, The Netherlands, 2015; pp. 269-291.

15. Chan, Y.H.; Yusup, S.; Quitain, A.T.; Tan, R.R.; Sasaki, M.; Lam, H.L.; Uemura, Y. Effect of process parameters on hydrothermal liquefaction of oil palm biomass for bio-oil production and its life cycle assess. Energy Convers. Manag. 2015, 104, 180-188. [CrossRef]

16. Asmadi, M.; Kawamoto, H.; Saka, S. Thermal reactions of guaiacol and syringol as lignin model aromatic nuclei. J. Anal. Appl. Pyrolysis 2011, 92, 88-98. [CrossRef]

17. Varanasi, P.; Singh, P.; Auer, M.; Adams, P.D.; Simmons, B.A.; Singh, S. Survey of renewable chemicals produced from lignocellulosic biomass during ionic liquid pretreatment. Biotechnol Biofuels 2013, 6, 14. [CrossRef] [PubMed]

18. Dutta, T.; Isern, N.G.; Sun, J.; Wang, E.; Hull, S.; Cort, J.R.; Simmons, B.A.; Singh, S. Survey of Lignin-Structure Changes and Depolymerization during Ionic Liquid Pretreatment. ACS Sustain. Chem. Eng. 2017, 5, 10116-10127. [CrossRef]

19. Prado, R.; Brandt, A.; Erdocia, X.; Hallet, J.; Welton, T.; Labidi, J. Lignin oxidation and depolymerisation in ionic liquids. Green Chem. 2016, 18, 834-841. [CrossRef]

20. Dai, J.; Patti, A.F.; Saito, K. Depolymerization of Lignin by Catalytic Oxidation in Ionic Liquids. In Encyclopedia of Ionic Liquids; Zhang, S., Ed.; Springer: Singapore, 2020; pp. 1-12.

21. Matsagar, B.M.; Hossain, S.A.; Islam, T.; Alamri, H.R.; Alothman, Z.A.; Yamauchi, Y.; Dhepe, P.L.; Wu, K.C.W. Direct Production of Furfural in One-pot Fashion from Raw Biomass Using Brønsted Acidic Ionic Liquids. Sci. Rep. 2017, 7, 13508. [CrossRef]

22. Matsagar, B.M.; Munshi, M.K.; Kelkar, A.A.; Dhepe, P.L. Conversion of concentrated sugar solutions into 5-hydroxymethyl furfural and furfural using Brönsted acidic ionic liquids. Catal. Sci. Technol. 2015, 5, 5086-5090. [CrossRef]

23. Zhang, J.; Deng, H.; Lin, L. Wet Aerobic Oxidation of Lignin into Aromatic Aldehydes Catalysed by a Perovskite-type Oxide: $\mathrm{LaFe}_{1-\mathrm{x}} \mathrm{Cu}_{\mathrm{x}} \mathrm{O}_{3}(\mathrm{x}=0,0.1,0.2)$. Molecules 2009, 14, 2747-2757. [CrossRef] [PubMed]

24. Walch, F.; Abdelaziz, O.Y.; Meier, S.; Bjelić, S.; Hulteberg, C.P.; Riisager, A. Oxidative depolymerization of Kraft lignin to high-value aromatics using a homogeneous vanadium-copper catalyst. Catal. Sci. Technol. 2021, 11, 1843-1853. [CrossRef]

25. Viseshsin, N.; Sukhitkul, P.; Panyadee, R.; Sakdaronnarong, C.; Posoknistakul, P. Study of vanillin formation under oxygen delignification process. In Proceedings of 2018 IEEE 5th International Conference on Engineering Technologies and Applied Sciences (ICETAS 2018), Bangkok, Thailand, 22-23 November 2018.

26. Panyadee, R.; Posoknistakul, P.; Jonglertjunya, W.; Kim-Lohsoontom, P.; Laosiripojana, N.; Matsagar, B.M.; Wu, K.C.W.; Sakdaronnarong, C. Sequential Fractionation of Palm Empty Fruit Bunch and Microwave-Assisted Depolymerization of Lignin for Producing Monophenolic Compounds. ACS Sustain. Chem. Eng. 2018, 6, 16896-16906. [CrossRef]

27. Tarabanko, V.E.; Tarabanko, N. Catalytic Oxidation of Lignins into the Aromatic Aldehydes: General Process Trends and Development Prospects. Int. J. Mol. Sci. 2017, 18, 2421. [CrossRef]

28. Wang, H.; Tucker, M.; Ji, Y. Recent Development in Chemical Depolymerization of Lignin: A Review. Appl. Chem. 2013, 2013, 838645. [CrossRef]

29. Matsagar, B.M.; Kang, T.-C.; Wang, Z.-Y.; Yoshikawa, T.; Nakasaka, Y.; Masuda, T.; Chuang, L.-C.; Wu, K.C.W. Efficient liquidphase hydrogenolysis of a lignin model compound (benzyl phenyl ether) using a Ni/carbon catalyst. React. Chem. Eng. 2019, 4, 618-626. [CrossRef]

30. Cabral Almada, C.; Kazachenko, A.; Fongarland, P.; Da Silva Perez, D.; Kuznetsov, B.N.; Djakovitch, L. Supported-Metal Catalysts in Upgrading Lignin to Aromatics by Oxidative Depolymerization. Catalysts 2021, 11, 467. [CrossRef]

31. Warner, G.; Hansen, T.S.; Riisager, A.; Beach, E.S.; Barta, K.; Anastas, P.T. Depolymerization of organosolv lignin using doped porous metal oxides in supercritical methanol. Bioresour. Technol. 2014, 161, 78-83. [CrossRef]

32. Ma, R.S.; Guo, M.; Zhang, X. Recent advances in oxidative valorization of lignin. Catal. Today 2018, 302, 50-60. [CrossRef] 
33. Abdelaziz, O.Y.; Meier, S.; Prothmann, J.; Turner, C.; Riisager, A.; Hulteberg, C.P. Oxidative Depolymerisation of Lignosulphonate Lignin into Low-Molecular-Weight Products with $\mathrm{Cu}-\mathrm{Mn} / \delta$-Al2O3. Top. Catal. 2019, 62, 639-648. [CrossRef]

34. Schutyser, W.; Kruger, J.S.; Robinson, A.M.; Katahira, R.; Brandner, D.G.; Cleveland, N.S.; Mittal, A.; Peterson, D.J.; Meilan, R.; Román-Leshkov, Y.; et al. Revisiting alkaline aerobic lignin oxidation. Green Chem. 2018, 20, 3828-3844. [CrossRef]

35. Li, Y.-x.; Zhu, J.-p.; Zhang, Z.-j.; Qu, Y.-S. Preparation of Syringaldehyde from Lignin by Catalytic Oxidation of Perovskite-Type Oxides. ACS Omega 2020, 5, 2107-2113. [CrossRef] [PubMed]

36. Wu, G.; Heitz, M.; Chornet, E. Improved Alkaline Oxidation Process for the Production of Aldehydes (Vanillin and Syringaldehyde) from Steam-Explosion Hardwood Lignin. Ind. Eng. Chem. Res. 1994, 33, 718-723. [CrossRef]

37. Arefieva, O.D.; Vasilyeva, M.S.; Zemnukhova, L.A.; Timochkina, A.S. Heterogeneous photo-Fenton oxidation of lignin of rice husk alkaline hydrolysates using Fe-impregnated silica catalysts. Environ. Technol. 2021, 42, 2220-2228. [CrossRef]

38. Das, L.; Xu, S.; Shi, J. Catalytic Oxidation and Depolymerization of Lignin in Aqueous Ionic Liquid. Front. Energy Res. 2017, 5, 1-12. [CrossRef]

39. Liu, Q.; Li, P.; Liu, N.; Shen, D. Lignin depolymerization to aromatic monomers and oligomers in isopropanol assisted by microwave heating. Polym. Degrad. Stab. 2017, 135, 54-60. [CrossRef]

40. Shao, L.; Zhang, Q.; You, T.; Zhang, X.; Xu, F. Microwave-assisted efficient depolymerization of alkaline lignin in methanol/formic acid media. Bioresour. Technol. 2018, 264, 238-243. [CrossRef]

41. Liu, X.; Bouxin, F.P.; Fan, J.; Gammons, R.; Budarin, V.L.; Hu, C.; Clark, J.H. Effect of metal triflates on the microwave-assisted catalytic hydrogenolysis of birch wood lignin to monophenolic compounds. Ind. Crop. Prod. 2021, 167, 113515. [CrossRef]

42. Liu, X.; Bouxin, F.P.; Fan, J.; Budarin, V.L.; Hu, C.; Clark, J.H. Microwave-assisted catalytic depolymerization of lignin from birch sawdust to produce phenolic monomers utilizing a hydrogen-free strategy. J. Hazard. Mater. 2021, 402, 123490. [CrossRef] [PubMed]

43. Lucarelli, C.; Giugni, A.; Moroso, G.; Vaccari, A. FT-IR Investigation of Methoxy Substituted Benzenes Adsorbed on Solid Acid Catalysts. J. Phys. Chem. C 2012, 116, 21308-21317. [CrossRef]

44. Jonglertjunya, W.; Juntong, T.; Pakkang, N.; Srimarut, N.; Sakdaronnarong, C. Properties of lignin extracted from sugarcane bagasse and its efficacy in maintaining postharvest quality of limes during storage. LWT-Food Sci. Technol. 2014, 57, 116-125. [CrossRef]

45. Li, J.; Zhang, J.; Zhang, S.; Gao, Q.; Li, J.; Zhang, W. Alkali lignin depolymerization under eco-friendly and cost-effective $\mathrm{NaOH} /$ urea aqueous solution for fast curing bio-based phenolic resin. Ind. Crop. Prod. 2018, 120, 25-33. [CrossRef]

46. Roberts, V.; Fendt, S.; Lemonidou, A.A.; Li, X.; Lercher, J.A. Influence of alkali carbonates on benzyl phenyl ether cleavage pathways in superheated water. Appl. Catal. B 2010, 95, 71-77. [CrossRef]

47. Manikandan, M.; Venugopal, A.K.; Nagpure, A.S.; Chilukuri, S.; Raja, T. Promotional effect of Fe on the performance of supported $\mathrm{Cu}$ catalyst for ambient pressure hydrogenation of furfural. RSC Adv. 2016, 6, 3888-3898. [CrossRef]

48. Sun, C.; Mao, D.; Han, L.; Yu, J. Effect of impregnation sequence on performance of $\mathrm{SiO}_{2}$ supported Cu-Fe catalysts for higher alcohols synthesis from syngas. Catal. Commun. 2016, 84, 175-178. [CrossRef]

49. Ye, Y.; Wang, L.; Zhang, Y.; Shan, J.; Tao, F. The role of copper in catalytic performance of a Fe-Cu-Al-O catalyst for water gas shift reaction. Chem. Commun. 2013, 39, 4385-4387. [CrossRef] [PubMed]

50. Li, L.; Ma, P.; Hussain, S.; Jia, L.; Lin, D.; Yin, X.; Lin, Y.; Cheng, Z.; Wang, L. FeS2/carbon hybrids on carbon cloth: A highly efficient and stable counter electrode for dye-sensitized solar cells. Sustain. Energy Fuels 2019, 3, 1749-1756. [CrossRef]

51. Chusuei, C.C.; Brookshier, M.A.; Goodman, D.W. Correlation of relative X-ray photoelectron spectroscopy shake-up intensity with $\mathrm{CuO}$ particle size. Langmuir 1999, 15, 2806-2808. [CrossRef]

52. Rahman, M.M.; Khan, S.B.; Marwani, H.M.; Asiri, A.M.; Alamry, K.A. Selective Iron(III) ion uptake using CuO-TiO2 nanostructure by inductively coupled plasma-optical emission spectrometry. Chem Cent. J. 2012, 6, 158. [CrossRef] [PubMed]

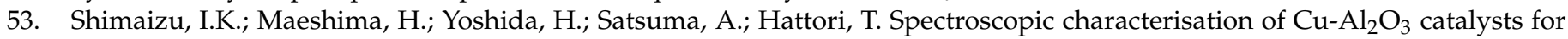
selective catalytic reduction of NO with propane. PCCP 2000, 2, 2435-2439. [CrossRef]

54. Mattisson, T.; Lyngfelt, A.; Leion, H. Chemical-looping with oxygen uncoupling for combustion of solid fuels. Int. J. Greenh. Gas. Control. 2009, 3, 11-19. [CrossRef]

55. Sun, H.; Zelekew, O.A.; Chen, X.; Guo, Y.; Kuo, D.-H.; Lu, Q.; Lin, J. A noble bimetal oxysulfide CuVOS catalyst for highly efficient catalytic reduction of 4-nitrophenol and organic dyes. RSC Adv. 2019, 9, 31828-31839. [CrossRef]

56. Song, H.; Shah, K.; Doroodchi, E.; Wall, T.; Moghtaderi, B. Analysis on Chemical Reaction Kinetics of $\mathrm{CuO} / \mathrm{SiO}_{2} \mathrm{Oxygen} \mathrm{Carriers}$ for Chemical Looping Air Separation. Energy Fuels 2014, 28, 173-182. [CrossRef]

57. Liang, Z.; Qin, W.; Dong, C. Experimental and Theoretical Study of the Interactions between $\mathrm{Fe}_{2} \mathrm{O}_{3} / \mathrm{Al}_{2} \mathrm{O}_{3}$ and $\mathrm{CO}$. Energies 2017, 10, 598. [CrossRef]

58. Matsuura, H.; Katada, N.; Niwa, M. Additional acid site on HZSM-5 treated with basic and acidic solutions as detected by temperature-programmed desorption of ammonia. Microporous Mesoporous Mater. 2003, 66, 283-296. [CrossRef]

59. Shen, J.; Cortright, R.D.; Chen, Y.; Dumesic, J.A. Microcalorimetric and Infrared Spectroscopic Studies of. gamma.- $\mathrm{Al}_{2} \mathrm{O}_{3} \mathrm{Modified}$ by Basic Metal Oxides. J. Phys. Chem. 1994, 98, 8067-8073. [CrossRef]

60. Sawa, M.; Niwa, M.; Murakami, Y. Derivation of new theoretical equation for temperature-programmed desorption of ammonia with freely occurring readsorption. Zeolites 1990, 10, 307-309. [CrossRef] 
61. Ouyang, X.; Ruan, T.; Qiu, X. Effect of solvent on hydrothermal oxidation depolymerization of lignin for the production of monophenolic compounds. Fuel Process. Technol. 2016, 144, 181-185. [CrossRef]

62. Nair, V.; Dhar, P.; Vinu, R. Production of phenolics via photocatalysis of ball milled lignin-TiO2 mixtures in aqueous suspension. RSC Adv. 2016, 6, 18204-18216. [CrossRef]

63. Felício, C.M.; Machado, A.E.d.H.; Castellan, A.; Nourmamode, A.; Perez, D.d.S.; Ruggiero, R. Routes of degradation of $\beta$-O-4 syringyl and guaiacyl lignin model compounds during photobleaching processes. J. Photochem. Photobiol. A Chem. 2003, 156, 253265. [CrossRef]

64. Luo, J.; Melissa, P.; Zhao, W.; Wang, Z.; Zhu, Y. Selective Lignin Oxidation towards Vanillin in Phenol Media. ChemistrySelect 2016, 1, 4596-4601. [CrossRef]

65. Yang, M.; Xu, A.; Du, H.; Sun, C.; Li, C. Removal of salicylic acid on perovskite-type oxide $\mathrm{LaFeO}_{3}$ catalyst in catalytic wet air oxidation process. J. Hazard. Mater. 2007, 139, 8692. [CrossRef]

66. Wu, G.; Heitz, M. Catalytic Mechanism of Cu2+ and Fe3+ in Alkaline $\mathrm{O}_{2}$ Oxidation of Lignin. J. Wood Chem. Technol. 1995, 15, 189-202. [CrossRef]

67. Xiang, Q.; Lee, Y.Y. Production of oxychemicals from precipitated hardwood lignin. Appl. Biochem. Biotechnol. 2001, 91, 71-80. [CrossRef]

68. Mukherjee, I.a.B.K.S. Renewable and, Palm oil-based biofuels and sustainability in southeast Asia: A review of Indonesia, Malaysia, and Thailand. Renew. Sustain. Energy Rev. 2014, 37, 1-12. [CrossRef]

69. Badamali, S.K.; Luque, R.; Clark, J.H.; Breeden, S.W. Unprecedented oxidative properties of mesoporous silica materials: Towards microwave-assisted oxidation of lignin model compounds. Catal. Commun. 2013, 31, 1-4. [CrossRef]

70. Xu, C.; Tang, S.-F.; Sun, X.; Sun, Y.; Li, G.; Qi, J.; Li, X.; Li, X. Investigation on the cleavage of $\beta$-O-4 linkage in dimeric lignin

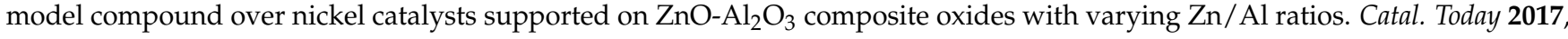
298, 89-98. [CrossRef]

71. Zhu, X.; Lobban, L.L.; Mallinson, R.G.; Resasco, D.E. Bifunctional transalkylation and hydrodeoxygenation of anisole over a Pt/HBeta catalyst. J. Catal. 2011, 281, 21-29. [CrossRef]

72. Massoth, F.E.; Politzer, P.; Concha, M.C.; Murray, J.S.; Jakowski, J.; Simons, J. Catalytic Hydrodeoxygenation of Methyl-Substituted Phenols: Correlations of Kinetic Parameters with Molecular Properties. J. Phys. Chem. B 2006, 110, 14283-14291. [CrossRef]

73. Cui, K.; Yang, L.; Ma, Z.; Yan, F.; Wu, K.; Sang, Y.; Chen, H.; Li, Y. Selective conversion of guaiacol to substituted alkylphenols in supercritical ethanol over MoO3. Appl. Catal. B 2017, 219, 592-602. [CrossRef]

74. Mai, F.; Cui, K.; Wen, Z.; Wu, K.; Yan, F.; Chen, M.; Chen, H.; Li, Y. Highly selective conversion of guaiacol to tert-butylphenols in supercritical ethanol over a H2WO4 catalyst. RSC Adv. 2019, 9, 2764-2771. [CrossRef] 